NBER WORKING PAPER SERIES

\title{
LIVING WAGE EFFECTS: NEW AND IMPROVED EVIDENCE
}

\author{
Scott Adams \\ David Neumark \\ Working Paper 9702 \\ http://www.nber.org/papers/w9702
}

\section{NATIONAL BUREAU OF ECONOMIC RESEARCH 1050 Massachusetts Avenue Cambridge, MA 02138}

May 2003

Adams is Assistant Professor of Economics, University of Wisconsin-Milwaukee. Neumark is Senior Fellow, Public Policy Institute of California; Professor of Economics, Michigan State University; and Research Associate, NBER. We thank Timothy Bartik, Mark Brenner, Kevin Hallock, Judith Hellerstein, Lori Kletzer, Michael Reich, anonymous referees, and participants at the Living Wage Research Conference at UCRiverside for helpful comments. Any opinions expressed in this paper are those of the authors alone and do not necessarily reflect any position of the Public Policy Institute of California. The views expressed herein are those of the authors and not necessarily those of the National Bureau of Economic Research.

(C)2003 by Scott Adams and David Neumark. All rights reserved. Short sections of text not to exceed two paragraphs, may be quoted without explicit permission provided that full credit including Cnotice, is given to the source. 
Living Wage Effects: New and Improved Evidence

Scott Adams and David Neumark

NBER Working Paper No. 9702

May 2003

JEL No. I2, J2, J3

\section{$\underline{\text { ABSTRACT }}$}

This paper explores the effects of living wages on low-wage workers and low-income families. First, we update our earlier analyses, using data for 1996-2002, and address a number of criticisms of those analyses. We confirm our earlier findings that business assistance living wage laws boost wages of the lowest-wage workers, at the cost of some disemployment, but on net reduce urban poverty. Second, we expand the analysis of distributional effects beyond looking just at the poverty threshold. We do not find that living wages increase the depth of poverty among families that remain poor, and we find that families somewhat below and somewhat above the poverty line are also helped by living wages. Finally, we suggest that the poverty reductions generated by living wages may stem from income gains for individuals with higher wages or skills who are nonetheless in poor families, rather than for the lowest-wage or lowest-skill individuals.

Scott Adams

Department of Economics

University of Wisconsin

Milwaukee, WI 53211

sjadams@uwm.edu
David Neumark

Public Policy Institute of California

500 Washington St., Suite 800

San Francisco, CA 94127

and NBER

neumark@ppic.org 


\section{Introduction}

Campaigns to implement living wages in metropolitan areas across the United States have continued apace since we conducted our first studies of the effects of living wages laws. In 2001 and 2002, living wage laws were implemented in seven additional large cities, and many smaller jurisdictions. The total number of living wage laws now in effect in the United States-including cities of all sizes, as well as counties and school boards-is near $90 .{ }^{1}$ Information on existing living wage laws for larger cities is provided in Table 1. As the table shows, living wage laws cover many of the nation's major cities-nine of the 20 largest cities based on the 2000 Census of Population-and campaigns are under way in additional cities. While we are not there yet, the rapid spread of living wage ordinances, beginning with Baltimore's in 1994, suggests that the claim of a major organizer of living wage campaigns that "In 10 years, there's going to be some form of living-wage ordinance in every city in the country," may be only moderately overoptimistic. $^{2}$

Our initial work on living wage laws estimated the effects of these laws on wages and employment of low-skill individuals, and on poverty rates in the urban areas in which living wages have been implemented (Neumark and Adams, forthcoming (a) and (b)). That research begins by asking whether there is evidence that living wage laws lead to detectable increases in wages at the lower end of the wage or skill distribution. ${ }^{3}$ While such effects are readily detectable with respect to minimum wages, the question arises with respect to living wages because of the low fraction of workers covered, and because of questions about enforcement. ${ }^{4}$ The evidence points to sizable effects of living wage ordinances on the wages of low-wage workers in the cities

\footnotetext{
${ }^{1}$ For current information, see www.epionline.org.

${ }^{2}$ This quote is attributed to Wade Rathke, chief organizer for the Association of Community Organizations for Reform Now (ACORN), in USA Today, July 23, 2002.

${ }^{3}$ The results are summarized here. Some of the details regarding the econometric analysis are provided later, and the reader is referred to our earlier work for additional details.

${ }^{4}$ For preliminary information on enforcement of living wage laws, see Sander and Lokey (1998).
} 
in which these ordinances are enacted. In fact, the magnitudes of the estimated wage effects (elasticities of approximately 0.07 for workers in the bottom tenth of the wage distribution) are much larger than would be expected based on the apparently limited coverage of city contractors by most living wage laws. Additional analyses that help reconcile these large effects indicate that the effects are driven by cities in which the coverage of living wage laws is generally broadernamely cities that impose living wages on employers receiving business assistance from the city, which is typically done in addition to covering contractors. ${ }^{5}$

Of course, the potential gains from higher wages may be offset by reduced employment opportunities. Overall, although the evidence of disemployment effects is statistically weaker than the evidence of positive wage effects, the estimated elasticity is -0.14 , which is sizable. Moreover, the disemployment effects tend to appear precisely where living wage laws generate positive wage effects-in particular, for low-skill workers covered by the broader laws that apply to employers receiving business assistance. Thus, as economic theory would lead us to expect, living wage laws present a trade-off between wages and employment.

This sets the stage for weighing these competing effects, in particular examining the effect of living wage laws on poverty in the urban areas in which they are implemented, which is the central policy question. ${ }^{6}$ Overall, the evidence suggests that living wages may be modestly successful at reducing urban poverty in the cities that have adopted such legislation. In particular, the probability that families have incomes below the poverty line falls in relative terms in cities that pass living wage laws. The estimates imply an elasticity of the proportion of poor families

\footnotetext{
${ }^{5}$ For these business assistance living wage laws, the estimated elasticity of wages with respect to living wages in the bottom decile of the wage distribution is approximately 0.1 , while for contractor-only living wage laws the estimated elasticity is small and indistinguishable from zero.

${ }^{6}$ For example, the web-site of the Economic Policy Institute, while noting that other anti-poverty tools are needed, argues that "the living wage is a crucial tool in the effort to end poverty" (www.epinet.org). And many living wages are set to lift a family with a single full-time, year-round worker to the poverty line.
} 
with respect to the living wage of about $-0.19 .^{7}$ Paralleling the findings for wage and employment effects, the impact on poverty arises only for the broader living wage laws that cover employers receiving business assistance from cities.

In interpreting this evidence, it is important to keep two things in mind. First, while economic theory predicts that raising mandated wage floors will lead to some employment reductions, it makes no predictions regarding the effects of living wages on the distribution of family incomes, or on poverty specifically. The distributional effects depend on both the magnitudes of the wage and employment effects, and on their incidence throughout the family income distribution. Second, a finding that living wage laws reduce poverty does not imply that these laws increase economic welfare overall (or vice versa). Living wage laws, like all tax and transfer schemes, generally entail some inefficiencies that may reduce welfare relative to the most efficient such scheme.

The present paper expands on our analysis of living wages in a number of potentially important ways, each of which responds to some limitations of our initial research or criticisms of that research. First, the spread of living wages to cities across the United States is a very recent phenomenon, with most living wage laws passed in the late 1990s. As a result, our initial analyses were based on a relatively small number of observations on cities with living wage laws, and nearly entirely on a period of strong economic growth. ${ }^{8}$ In this paper, we incorporate new data available through 2002. The extension of the sample period by two years provides a valuable opportunity to update our estimates, extending the sample to include a period in which many

\footnotetext{
${ }^{7}$ This seems like a large effect, given a wage elasticity for low-wage workers of approximately 0.1 . Of course, no one is claiming that living wages lift a family from well below the poverty line to well above it. But living wages may help nudge a family over the poverty line, and we have to recall that these average wage effects are likely manifested as much larger gains concentrated on a possibly quite small number of workers and families. Thus, even coupled with some employment reductions, living wages can lift a detectable number of families above the poverty line.

${ }^{8}$ For this reason, in our earlier work we had cautioned that "More work will need to be done to evaluate whether the evidence we find holds up in a larger sample of cities that have adopted such legislation over a longer period of time" (Neumark and Adams, forthcoming (b), p. 28).
} 
regions-some with living wages, and some without-experienced downturns in economic activity after a long and sustained expansion. In re-examining this evidence, we also address some criticisms of our initial findings.

Second, a focus on whether living wages push families above (or below) the poverty level may mask other important distributional effects. The poverty threshold is, of course, a widelyused measure, but one that can easily be viewed as arbitrary, and an exclusive focus on whether families are above or below the poverty threshold potentially misses a richer set of effects of living wages on low-income families either below or above this threshold. Thus, in this paper we present a more in-depth analysis of the distributional effects of living wages, moving beyond a focus on the poverty rate to examine changes in income experienced by poor families and by lowincome families above the poverty threshold.

Third, in some respects the positive wage effects and negative employment effects of living wages may appear difficult to square with the reductions in poverty that living wages generate, especially given that the disemployment elasticity exceeds the wage elasticity. In principle, given that the distribution of wage and employment changes across families can occur in a variety of ways, there is no necessary inconsistency in these findings. For example, the wage gains could occur for workers in poor families, and the employment losses for workers in nonpoor families, some of which remain non-poor. Nonetheless, in this paper we report on analyses of living wage effects at different points of the wage distribution and look at the relationship between low-wage work and poverty, to see if the individual-level results on wages and employment and the family-level results on poverty can be reconciled in a more satisfactory way. This analysis leads to some additional, substantively interesting findings and "refinements" regarding the effects of living wages. 


\section{Data and Methods}

Table 1 lists information on living wage laws in all cities that are identified in our data and end up yielding enough observations on individuals or families to be included in our sample (based on criteria discussed below), including the wage floors and their effective dates and information on who is covered by these laws. ${ }^{9}$

The data on labor market outcomes and other worker-related characteristics come from the Current Population Survey (CPS) monthly Outgoing Rotation Group files (ORGs) extending from January 1996 through December 2002, and the CPS Annual Demographic Files (ADFs) from 1996 through 2002 (the ADFs elicit information on the previous calendar year). The ORG files are preferable for the analysis of individual-level outcomes-wages and employment-because they have information on current wages and provide a sample three times as large. Because cities cannot be identified in the ORG files for a period in 1995, coupled with the fact that most living wage laws came into effect in 1996 or after, we restrict the sample to begin in $1996 .{ }^{10}$ In contrast, the ADFs provide the data set of choice when analyzing the effects of living wages on poverty, because the measures of income in the ADFs correspond to those used in defining poor families by including non-earned family income and transfer payments and by measuring income on an annual basis. We therefore use the ADFs for the estimates of the effects of living wages on poverty.

In these files, residents of all SMSAs, encompassing all large- and medium-sized cities in the United States, can be identified. We extract data on these residents for our empirical analysis. In some respects, we would like to know where people work rather than where they live, but such

\footnotetext{
${ }^{9}$ Some living wage ordinances specify two different wage floors, a lower one applicable when health insurance is provided, and a higher one when it is not. Table 1 reports the lower wage floor, and the empirical results we report use the lower wage floor applicable when health insurance is provided.

${ }^{10}$ Specifically, for part of 1995 SMSA codes are unavailable in the ORGs due to phasing in of a new CPS sample based on the 1990 Census.
} 
information is not available, and employees of firms covered by living wage laws need not work in the SMSA. Also, the correspondence between cities and SMSAs is imperfect, but because many suburban residents may work in the city, this is not necessarily inappropriate. ${ }^{11}$ Since January 1996, the design of the CPS has resulted in the large- and medium-sized metropolitan areas in the sample being self-representing (U.S. Bureau of the Census, 1997), ${ }^{12}$ which is another reason we use information only from January 1996 on. ${ }^{13}$

The CPS has some disadvantages and some advantages for studying the effects of living wages. Given that the CPS is a household-based survey with virtually no information on employers, it is not possible to identify covered and uncovered workers. Instead, all we can identify (and therefore the only information we exploit in the empirical analysis) is the city in which a worker lives and the type of law prevailing there. Obviously, therefore, CPS data are not useful in exploring the microeconomic effects of living wages at the firm or establishment leveli.e., questions such as whether firms engage in substitution away from low-wage labor, how much wages are increased for their lowest-wage workers, how employment responds, whether turnover falls, etc. Such questions are best addressed using direct survey data on covered employers (and ideally a control group of uncovered or unaffected employers), as has begun to occur in some recent research (e.g., Brenner, 2003; Fairris, 2003). On the other hand, the CPS data are very useful (and perhaps the best data available at present) for addressing policy questions regarding the effects of living wages on low-wage workers and low-income families, because they permit us to estimate the net effects (including indirect or perhaps "general equilibrium" effects) of living

\footnotetext{
${ }^{11}$ For expositional ease, from this point on we often refer to cities rather than SMSAs.

${ }^{12}$ In a small number of cases, though, outlying counties are excluded from the CPS sampling frame for an SMSA, in which case the data are representative of the remainder of the SMSA.

${ }^{13}$ With the ADFs we are able to obtain one earlier year of data. Because family income information in 1995 is reported in the $1996 \mathrm{ADF}$, for which SMSA codes are available, information on family income and city of residence for 1995 can also be used in the empirical analysis with the ADFs. Although most living wage activity starts up somewhat later, data from 1995 are useful in the case of living wages in a couple of cities, and for the control group. The poverty results, however, are in no way driven by 1995 data. When we excluded observations from 1995 from the sample, the results were qualitatively similar.
} 
wage laws on workers and families in the cities where they are passed, relative to other cities. Ultimately, the two types of data and research are complementary and inform each other, with firm-level data allowing researchers to test propositions about the individual-level behavioral responses of employers and workers to the imposition of living wages, and city-level data allowing researchers to assess the policy consequences.

\section{Evidence on Effects of Living Wages on Low-Wage Workers and Low-Income Families}

This section provides estimates of the effects of living wages on wages, employment, and poverty using the CPS data through 2002. Along the way, we briefly explain and discuss our empirical approach. Much of this discussion takes place in the context of estimating effects on wages, but carries over to the other analyses.

\section{Wages}

We estimate a wage equation for various ranges of the wage distribution in SMSAs. Specifically, we look at workers that fall below the $10^{\text {th }}$ centile, between the $10^{\text {th }}$ and $25^{\text {th }}$ centiles, between the $25^{\text {th }}$ and $50^{\text {th }}$ centiles, and between the $50^{\text {th }}$ and $75^{\text {th }}$ centiles of their city's wage distribution in a particular month. ${ }^{14}$ Pooling data across months, we estimate the following regression for each centile range

$$
\begin{aligned}
\ln \left(\mathrm{w}^{\mathrm{p}} \mathrm{jst}\right) & =\alpha+\mathrm{X}_{\mathrm{ijst}} \omega+\beta \cdot \ln \left(\mathrm{w}^{\mathrm{min}}{ }_{\mathrm{jst}}\right)+\gamma \cdot \max \left[\ln \left(\mathrm{w}_{\mathrm{jst}}^{\operatorname{liv}}\right), \ln \left(\mathrm{w}^{\mathrm{min}}{ }_{\mathrm{jst}}\right)\right] \\
& +\delta_{\mathrm{Y}} \mathrm{Y}_{\mathrm{t}}+\delta_{\mathrm{M}} \mathrm{M}_{\mathrm{s}}+\delta_{\mathrm{C}} \mathrm{C}_{\mathrm{j}}+\theta \cdot \mathrm{T}+\theta_{\mathrm{LW}} \cdot \mathrm{T} \cdot \mathrm{LW}_{\mathrm{js}}+\varepsilon_{\mathrm{ijst}} .
\end{aligned}
$$

This specification requires some explanation. $\mathrm{w}^{\mathrm{p}}$ is the hourly wage for individuals in the specified range $(p)$ of the wage distribution, such as those below the $10^{\text {th }}$ centile of the wage distribution. The subscripts ' $i$ ', 'j', 's', and 't' denote individual, city, month, and year. $\varepsilon$ is a random error term. $\mathrm{X}$ is a vector of individual characteristics (age, sex, race, education, and

\footnotetext{
${ }^{14}$ For the estimation of wage effects, we restrict our sample to workers with an hourly wage greater than one dollar and less than or equal to 100 dollars. We also limit the sample to those between the ages of 16 and 70, inclusive. The latter restriction is also applied to the employment analysis.
} 
marital status), $\mathrm{w}^{\mathrm{min}}$ is the higher of the federal or state minimum wage, ${ }^{15}$ and $\mathrm{w}^{\text {liv }}$ is the higher of the living wage or the minimum wage. $\mathrm{Y}, \mathrm{M}$, and $\mathrm{C}$ are vectors of year, month, and city (SMSA) dummy variables. $\mathrm{T}$ is a linear time trend. $\mathrm{LW}_{\mathrm{js}}$ is an indicator for cities that adopt a living wage ordinance at any point during the sample period, and has only a 'js' subscript to indicate that it is zero or one for the entire sample period.

The living wage variable that multiplies $\gamma$ is specified as the maximum of the (logs of the) living wage and the minimum wage. It is essential to control for minimum wages separately, because many cities with living wages are in states with high minimum wages, and we want to estimate the independent effects of living wages. The specification of the living wage effect imposes the minimum as the wage floor in the absence of a living wage. However, because living wages may have different effects from minimum wages, the coefficient is allowed to differ from that of the standard minimum wage floor. If living wages boost the wages of low-wage workers, we would expect to find positive estimates of $\gamma$ when we are looking at workers in relatively low ranges of the wage distribution. We also estimate specifications in which we lag $\ln \left(\mathrm{w}^{\mathrm{min}}\right)$ and $\ln \left(\mathrm{w}^{\text {liv }}\right)$ by six or 12 months, to allow for slower, adaptive responses to changes in minimum wages and living wages. Finally, we estimate specifications that allow the effects of living wages to differ in cities with contractor-only living wage laws and cities with broader business assistance living wage laws, by interacting $\ln \left(\mathrm{w}^{\mathrm{liv}}\right)$ inside the max operator in equation (1) with dummy variables for each type of living wage law.

The year and month dummy variables control for common changes across cities in the sample that could otherwise be confounded with living wage effects, since living wages are typically enacted later in the sample period. The city dummy variables control for the possibility

\footnotetext{
${ }^{15}$ In the few cases of SMSAs that straddle states with different minimum wages in some years (Davenport-Quad Cities, Philadelphia, Portland, and Providence), we use a weighted average of the minimum wages in the two states, weighting by the shares of the SMSA population in each state (averaged over the months of 1996).
} 
that living wage laws are passed in cities with either particularly high or low wages, which would again confound the estimation of their effects. Thus, this specification identifies an effect of the living wage when the dependent variable changes differentially in cities that pass living wage laws (or increase their living wage) relative to cities that do not pass living wage laws-a difference-indifferences research design.

The difference-in-differences strategy is predicated on the assumption that absent the living wage, and aside from differences captured in the other control variables, the treatment and control groups are comparable. Note, though, that explicit controls for local labor market conditions are not included. While local labor market conditions can surely matter, they are also potentially endogenous if, for example, living wages cause some job loss. Fixed differences in economic conditions between the treatment and control groups are captured in the city dummy variables, and the year and month dummy variables capture changes in economic conditions common to all cities. However, a potential problem arises if economic conditions are changing differentially by location. For this reason, to capture some dimensions of differing changes in economic conditions across cities, equation (1) also includes differential linear time trends for cities that do and do not pass living wage laws over the sample period. The difference in the trend for cities passing living wage laws is captured in the term $\theta_{\mathrm{LW}} \cdot \mathrm{T} \cdot \mathrm{LW}_{\mathrm{js}}$. When we estimate specifications that distinguish between contractor-only and business assistance living wage laws, we allow separate trends for each subset of living wage cities. ${ }^{16}$ While these trends do not capture every possible variation in local economic conditions, they will capture systematic differences between the different groups of cities in the rates of change of wages (and the other dependent

\footnotetext{
${ }^{16} \mathrm{We}$ also experimented with allowing nonlinear trends by adding quadratic terms in $\mathrm{T}$, but the results were very similar to those we report.
} 
variables) that are studied. ${ }^{17}$

When cities have very few observations for a given month, determining whether a worker falls in a particular range of the distribution is impossible or unreliable. We therefore restrict our sample for each analysis to workers in city-month cells with at least 25 observations, although many have far more observations. All SMSAs identified in the CPS and meeting the sample size restrictions are included in the analysis.

Finally, it is important to emphasize that unmeasured changes that occur in cities contemporaneously with the adoption of living wage laws cannot be easily separated from the living wage laws themselves. This is potentially important, since living wage laws are typically not passed in a vacuum but instead occur in the context of intensive efforts by community and labor groups that may have independent effects on low-wage labor markets, as well as influence the implementation and enforcement of living wage laws. ${ }^{18}$ As such, what this strategy may identify is the combined effects of living wage laws and other changes that accompany successful living wage campaigns, rather than the effects of the ordinances in isolation. This implies that we should not necessarily think of living wage laws only in terms of their impact on directly affected workers (i.e., low-wage workers performing covered work), and, from a policy perspective, that we need to better understand under what conditions living wage laws have more significant effects.

The evidence on the effects of living wages on wages is reported in Table 2. The oddnumbered columns report estimates for a single living wage variable, while the even-numbered

\footnotetext{
${ }^{17}$ Another issue we addressed in our earlier work was whether the extensive welfare reform that occurred in the latter part of the 1990s, which varied considerably across states, confounded the estimation of the effects of living wages. Because our earlier work covered the sample period 1996-2000 this was a particularly serious concern. To address it, we augmented the specification to identify the effects of living wages only from within-state variation-e.g., from cities with living wages paired with other cities in the same state that did not have living wages. Because welfare reform is done at the level of the state, this approach sweeps out any common changes in low-wage labor markets across cities within a state. We found that estimating the models this way had little impact on the estimates and no impact on the conclusions.

${ }^{18}$ We are grateful to Michael Reich for emphasizing this point.
} 
columns break out separate effects (via interactions) for the generally broader living wage laws that extend to employers receiving business assistance and the narrower contractor-only living wage laws. In the lowest range of the wage distribution-at or below the $10^{\text {th }}$ centile in the SMSAmonth cell-we find no evidence of effects of living wage laws generally until about 12 months after the living wage is implemented. The estimated coefficient on the 12-month lag, 4.01 in column (1), implies an elasticity of about 0.04 , but is not statistically significant at the ten-percent level. ${ }^{19}$ However, when we estimate separate effects for business assistance and contractor-only living wage laws we find a significant impact only of business assistance laws. As shown in column (2), the estimated elasticity is 0.06 , significant at the ten-percent level.

It turns out that there is little difference in the trend in wages between living wage cities overall and cities that did not pass living wage laws. However, in the specifications that distinguish between contractor-only and business assistance living wages, the trends were quite different. The estimated trend for cities passing business assistance living wage laws was positive relative to the control group (for wages, employment, and reductions in poverty), with the difference generally statistically significant. The estimated trend for cities passing contractor-only living wage laws was negative relative to the control group, with the difference smaller but sometimes statistically significant. Because the underlying relative trend in economic conditions in the cities passing business assistance living wage laws was positive, specifications excluding this trend tended to show stronger positive effects of these living wage laws on wages. The same results carry over to the findings reported below for employment and poverty; when the different trends were excluded the results suggested weaker negative effects on employment of less-skilled

\footnotetext{
${ }^{19}$ A reader comparing results in this paper and our earlier work will notice that the sample does not go up quite in proportion to the number of observations added simply by using additional years of data. The reason is that four cities passed living wage laws in 2000 or 2001 (Buffalo, Omaha, and St. Louis in 2000, and Pittsburgh in 2001), but then did not implement them, so we thought it best to exclude them from the sample. We verified that excluding these cities from the estimates for the sample period used in our earlier papers had virtually no effect on the estimates, so the changes in the updated estimates are due principally to the additional data.
} 
individuals, and a stronger impact in reducing poverty.

The remaining columns repeat these estimates for progressively higher ranges of the wage distribution. Looking at the general effect of living wage laws in these higher ranges, all of the estimates are positive although all but one are statistically insignificant, providing little evidence of effects of living wages higher up in the wage distribution. When we focus on the effects of business assistance living wage laws at higher ranges, specifically between the $10^{\text {th }}$ and $50^{\text {th }}$ centiles, the coefficients are generally larger, with one statistically significant at the ten-percent level and one at the five-percent level. While the evidence clearly points to effects on wages primarily at the lower end of the wage distribution, we return below to some of this evidence regarding higher-wage workers, when we move on to a more-detailed exploration of some of the distributional effects of living wages.

Numerous issues arise concerning estimating the equation for those with wages below (or above) a given threshold. The key point to keep in mind, though, is that the selection on those below a given threshold is not problematic as long as we interpret the regression as estimating effects on a conditional mean. Note that even if living wages tend to be above the $10^{\text {th }}$ centile of the wage distribution, if they raise wages of some workers initially below the $10^{\text {th }}$ centile to above the $10^{\text {th }}$ centile, then the average wages of workers below the $10^{\text {th }}$ centile will clearly increase. ${ }^{20}$ And similarly if some workers drop down below the $10^{\text {th }}$ centile, then the average below the $10^{\text {th }}$ centile has to have fallen, since those workers' wages must be below the wages of some workers previously below the $10^{\text {th }}$ centile. $^{21}$

\footnotetext{
${ }^{20}$ To see this in a simple example, suppose there are initially 50 workers, with five earning a wage of $\$ 5,20$ earning $\$ 6$, and 25 earning $\$ 7$, so the $10^{\text {th }}$ centile (the wage of the fifth worker from the bottom when workers are ranked by wages) is $\$ 5$. Now let one worker's wage go from $\$ 5$ to $\$ 7$. In this case, the $10^{\text {th }}$ centile rises to $\$ 6$, as the bottom tenth of the wage distribution now includes four workers earning $\$ 5$ and one worker earning $\$ 6$, and the average wage of workers at or below the $10^{\text {th }}$ centile rises from $\$ 5$ to $\$ 5.20$.

${ }^{21}$ With longitudinal data one could make some improvements in this type of analysis, as, for example, in the analysis of minimum wage effects in Neumark, et al. (2002). But with the relatively small number of cities and short sample
} 


\section{Criticisms of Estimated Wage Effects}

Criticism of our estimation of the effects of living wages on the lowest-wage workers has been raised quite forcefully by Brenner, Wicks-Lam, and Pollin (2002). They argue that our truncated regression model leads to serious bias. This model does lead to biased estimates of population regression functions, which is why we have pointed out all along that the regression must be interpreted as a conditional mean. Brenner, et al., then proceed to argue that a quantile regression approach should be used to avoid this bias. As evidence that our method leads to substantial bias, they first replicate (exactly) our results for wages below the $10^{\text {th }}$ centile. They then estimate a quantile regression for the $10^{\text {th }}$ centile, including the same skill-related control variables as in the vector $\mathrm{X}$ in equation (1). The difference in results is striking. Whereas our initial estimate of the wage effect below the $10^{\text {th }}$ centile is 6.95 (and significant), the quantile regression estimate is 0.74 (and insignificant). ${ }^{22}$

However, the quantile regression that Brenner, et al. (2002) estimate does not in fact estimate the effect of living wages on the lowest-wage workers, so it is perfectly natural that it fails to detect the positive wage effects that we find. To understand the problem with their approach, note that our regression approach looks at the wage distribution without conditioning on skill, picks out those below the $10^{\text {th }}$ centile in each city-month cell, and then estimates equation (1). So this regression asks whether living wages increase the wages of the lowest-wage workersthose below the $10^{\text {th }}$ centile-in the cities where they are passed. This parallels quite closely asking whether living wages shift the $10^{\text {th }}$ centile itself. Indeed in the work cited by Brenner, et al. (Neumark, 2002, p. 54), it was explicitly noted that the results were very similar if the regressions were simply estimated at the city-month level using the $10^{\text {th }}$ wage centile as the dependent

period, the loss of data associated with matching observations in the CPS leaves too little data to draw reliable inferences, although this is something worth taking up down the road when more data are available.

${ }^{22}$ Because their critique was based on our earlier papers using data through 2000 , we use the same data in this subsection. 
variable. $^{23}$

In contrast, by estimating a quantile regression including the skill-related control variables, Brenner, et al. (2002), are studying the wage distribution conditional on skill, and their regression asks whether living wages shift the wages of those at the $10^{\text {th }}$ centile of this conditional wage distribution. But why would we expect living wages to shift the wages of all workers whose wages are low relative to those with similar characteristics, even among workers with characteristics associated with high wages? Living wage laws impose a wage floor on absolute wages, not relative wages within skill groups.

This point is made clear in Figure 1. The top panel illustrates an analysis that, like ours, does not condition on skills. ${ }^{24}$ This analysis simply asks whether the $10^{\text {th }}$ centile of the wage distribution, for example, shifts with living wages. (We ask whether the mean below the $10^{\text {th }}$ centile shifts, but these two analyses should provide similar answers, which we verified.) Skillrelated controls can be included in a regression for this centile, to control for the possibility that, for example, education levels have risen in some cities leading to a shift in the lower tail of the wage distribution. But regardless, this analysis detects the impact of living wages on the wages of the lowest-wage workers. In contrast, the bottom panel illustrates the analysis in Brenner, et al. (2002). In the figure, we condition on one skill-related variable-education-while they condition on many, but the point is the same. Their quantile regression analysis asks whether the $10^{\text {th }}$ centile of the distribution of wage residuals conditional on education is shifted by living wages. But this

\footnotetext{
${ }^{23}$ Brenner, et al. (2002) cite Koenker and Hallock (2001) in claiming that our method of estimating wage effects (in equation (1)) yields "disastrous results" (footnote 4). But Koenker and Hallock raise this point in the context of a specific example (estimating Engel curves). Furthermore, Koenker and Hallock write this in reference to the approach of "segmenting the response variable into subsets according to its unconditional distribution and then doing least squares fitting on these subsets" (2001, p. 147). That is clearly not what we do, as we divide the sample into citymonth cells, and then look at those below the $10^{\text {th }}$ centile in each cell. In fact, what we do is much closer to what Koenker and Hallock suggest as a valid approach: to disaggregate the data into distinct cells (in our case by city and month), compute the centiles, and then project these on a more parsimonious (e.g., linear) model. Indeed, the regression for the centiles described in the text (and reported below) is exactly this approach.

${ }^{24}$ The figure should be interpreted as studying the wage distribution after sweeping out city and month effects.
} 
would be the case only if living wages shifted not just the wages of low-wage workers, but the wages of higher-education, higher-wage workers who earn lower wages than other workers with similar education (i.e., those at the $10^{\text {th }}$ centile of the "slice" of the wage distribution at each education level). There is no reason to expect this latter effect, which is presumably why they find no statistical evidence of a positive effect of living wage laws on wages when they estimate their quantile regression.

This argument is verified empirically in the estimates reported in Panel A of Table 3. The first column is the estimated effect of the living wage, lagged 12 months, from equation (1); this is the estimate on which the critique focuses. Column (2) shows the results obtained, instead, when the data are aggregated up to the city-month level, and a regression is estimated for the $10^{\text {th }}$ centile (without control variables). As noted above, this yields a qualitatively similar result to the estimate in column (1). Column (3) replicates the conditional-on-skill quantile regression estimate reported by Brenner, et al. (2002). The reason for the sharp drop in the estimate, as we note, is that this regression is measuring changes in wages for a mix of low-skill and high-skill workers who are low-wage relative to comparable workers, rather than low-wage in an absolute sense. But living wage laws, of course, regulate low wages in an absolute sense only. Thus, column (4) instead estimates the same quantile regression, without including the skill-related controls. As expected, the resulting estimate is in line with our estimates for either wages below the $10^{\text {th }}$ centile, or the $10^{\text {th }}$ centile itself. Thus, as long as the regression model considers the effect of living wages on low wages in an absolute sense--which is the only sensible question given the nature of living wage laws-the evidence in fact points to positive wage effects.

Brenner, et al. (2002) raise some other objections to our estimation of the effects of living wage laws. Some of these objections pertain to estimation of effects on wages as well as employment, but they can be covered in the context of the estimation of wage effects. One 
objection concerns the utility of the CPS in estimating the effects of living wage laws, because, they argue, the CPS data could not possibly yield enough observations on covered workers to reliably estimate the effects of living wages. They present a calculation for Los Angeles based on their estimate of 7,600 workers covered by the contractor clause of the city's living wage law, which constitutes 0.17 percent of the workforce in Los Angeles-Long Beach, and the fact that "in 1997 the CPS sampled approximately 5000 wage earners in the Los Angeles-Long Beach PMSA" (p. 13). Brenner, et al., then assume that we require 25 (or 30) covered workers in our sample from Los Angeles-Long Beach to obtain reliable estimates, and calculate that the odds of getting 25 workers is one in 500,000 (falling to one in $244,000,000$ for 30 workers). We do not know the basis for the assumption regarding how many covered workers we require for one particular city in our sample. But even if we accept their criterion for Los Angeles, and follow them in focusing only on coverage of contractors' employees-ignoring the fact that our wage effects arise for business assistance provisions of living wage laws, and the possibility that wage effects may arise for other workers ${ }^{25}$ - this calculation is in error. The Los Angeles living wage law took effect in April 1997, and hence if the CPS samples 5,000 wage earners per year, the relevant sample size is approximately $18,750(5,000$ multiplied by the $3-3 / 4$ years that the living wage law was in effect in our original sample). In this case, just based on their coverage estimate, the expected number of covered workers in the sample would be 31 (interestingly, one more than the number that they argue we would meet or exceed with a probability of one in $244,000,000) .{ }^{26}$

Perhaps the more general issue is whether the CPS is an appropriate data set with which to study the effects of living wage laws, because whatever the calculation, the number of directly covered workers is relatively small. In this vein, we remind the reader of our discussion in Section

\footnotetext{
${ }^{25}$ See, e.g., Pollin and Luce (1998, pp. 103-9) on "ripple effects."

${ }^{26}$ Based on this calculation, for estimating the 12-month lagged effect the expected number of covered workers in the sample would be 23 , just under the number that they argue we would meet or exceed with a probability of one in 500,000 .
} 
II highlighting the relative strengths of city-based data like the CPS that can be used to identify net effects of living wage laws, versus survey data from affected employers that can be used to study behavioral responses. If CPS data that include a relatively large numbers of workers and families from many cities cannot detect an effect of living wage laws (as is the case with contractor-only laws), then one can conclude that the policy had no net effect, even if small numbers of workers were affected; and similarly, concluding that there were no net effects of the policy is different from concluding that living wages did not affect some workers.

Another objection is that our wage results are driven by workers in Los Angeles, in particular that the results "rest on a sample weighted heavily toward just sub-minimum wage workers in Los Angeles" (p. 28). We frankly have been unable to piece together how they reached this conclusion. However, as a simple means of examining this claim, Panel B of Table 3 shows that if we simply exclude workers in Los Angeles from our sample--which strikes us as the simplest test of their proposition-the estimated wage effects are virtually unchanged. ${ }^{27}$

\section{Employment}

We use the same basic empirical framework to study employment, with only two differences. First, we estimate linear probability models for individual employment status. Second, we cannot classify non-working individuals based on their position in the wage distribution. Instead, we impute wages for everyone and group individuals based on their position in the distribution of imputed wages, or "skills.",28

The results are reported in Table 4, in a format paralleling the analysis of wages in Table 2.

\footnotetext{
${ }^{27} \mathrm{We}$ also verified that the qualitative conclusions are robust to excluding those workers from the bottom decile of the wage distribution that earn less than the minimum wage, which addresses the claim that our results are driven by subminimum wage workers.

${ }^{28} \mathrm{We}$ do this in a simple manner, estimating a standard log wage regression with year and month controls, and using predicted log wages from the estimated regression to construct imputed wage distributions for the SMSA-month cell. Of course, the market wages faced by those who choose not to work may be lower than those faced by observationally-equivalent individuals who choose to work; this is the standard sample selection problem. We have verified that reducing the imputed wages of the non-workers by five percent and ten percent led to results that were qualitatively similar.
} 
For living wages generally, in column (1), we find an estimated disemployment effect that is significant at the five-percent level at a lag of 12 months, paralleling the wage results. The estimated coefficient of -5.25 implies an elasticity of about -0.12 . When we estimate separate effects of business assistance and contractor-only living wage laws, in column (2), both estimates are negative, but we find a significant disemployment effect only for business assistance living wage laws, and the difference in the estimated coefficients is quite pronounced $(-7.39$ versus -2.88). This parallels the findings for wages, as we might expect, since it is presumably the wage effect that generates the disemployment effect.

Between the $10^{\text {th }}$ and $50^{\text {th }}$ centiles of the skill (i.e., imputed wage) distribution the point estimates of the effects of business assistance living wage laws are positive, consistent with substitution toward these workers. However, none of these estimates approach statistical significance.

\section{Poverty}

To examine the impact of living wages on poverty, we estimate linear probability models for the full sample of families from the ADFs of the form:

$$
\begin{aligned}
\mathrm{P}_{\mathrm{ijt}}=\alpha+ & \beta \cdot \ln \left(\mathrm{w}^{\mathrm{min}}{ }_{\mathrm{jt}}\right)+\gamma \cdot \max \left[\ln \left(\mathrm{w}^{\mathrm{liv}}{ }_{\mathrm{jt}}\right), \ln \left(\mathrm{w}^{\mathrm{min}}{ }_{\mathrm{jt}}\right)\right] \\
& +\delta_{\mathrm{Y}} \mathrm{Y}_{\mathrm{t}}+\delta_{\mathrm{C}} \mathrm{C}_{\mathrm{j}}+\theta \cdot \mathrm{t}+\theta_{\mathrm{LW}} \cdot \mathrm{t} \cdot \mathrm{LW}_{\mathrm{j}}+\varepsilon_{\mathrm{ijt}} .
\end{aligned}
$$

where $\mathrm{P}$ is an indicator for whether the family's total income is below the poverty threshold, and 'i’ now indexes families. ${ }^{29}$

The estimates are reported in Table 5. Looking at living wage laws overall, in column (1), the evidence points to a negative impact about one year after a living wage is implemented. The estimated coefficient of -3.42 is significant at the five-percent level, and implies an elasticity of -0.18 . Column (2) estimates separate effects of the two types of living wage laws. This yields

\footnotetext{
${ }^{29}$ In the poverty analysis we exclude families with members aged 65 and over, to avoid the influence of Social Security income.
} 
negative point estimates for both types of living wage laws, but only the estimated effect of business assistance living wage laws is statistically significant, and the estimate is larger than for contractor-only living wage laws.

\section{Business Assistance versus Contractor-Only Living Wage Laws}

A natural question that arises in the wage, employment, and poverty analysis is why we generally find little evidence of effects of contractor-only living wage laws, but stronger effects of business assistance living wage laws. This finding has met with some skepticism, based on the argument that few workers have actually been affected by these provisions of living wage laws. As an example, returning to Brenner, et al.'s (2002) discussion of our results using the data through 2000, they claim that none of the cities in our studies "had actually implemented the business assistance provision in their living wage laws during the period 1995 to 1999” (p. 16). Even if we take this claim at face value, it is a curious claim, as it is largely irrelevant whether these laws were in force in the 1995-1997 period. First of all, with the exception of Los Angeles and Minneapolis, none of the cities in our sample passed business assistance living wage laws until April 1998 at the earliest, and some were passed in 1999. Since the effects of business assistance living wage laws that we detect tend to occur with a lag of 12 months, most of these effects are identified from data beginning in 1999 at the earliest.

We were curious about the assertion that the laws were not implemented, and therefore investigated this claim for three of the cities that passed the earliest business assistance laws: Minneapolis, Oakland, and Los Angeles. For Minneapolis, we spoke with the individual who described himself as the "living wage point person" in the first year or so of the law, in the Minneapolis Community Development Agency. This individual stated that the agency devoted attention to the law immediately after its passage, but that it took about 12 to 18 months for uniform guidelines for implementation and enforcement to be put in place. For Oakland, we 
spoke to the responsible Contract Compliance Office in the City Manager's office. This

individual said that because the law took effect a few months after passage, there was time to get implementation and enforcement mechanisms into place. Thus, beginning with the effective date, living wage requirements were imposed. Finally, for Los Angeles, Brenner, et al. (2002) report interviewing the responsible person in the Office of the City Administrator. However, that office did not have responsibility for the living wage until February 1999, which could explain why they obtained the answer that the business assistance provision was not implemented earlier. Prior to 1999 responsibility lay with the Living Wage Section of the Office of Contract Compliance, and the responsible individual in that office indicated that implementation took place right away, although naturally it took time to create consistent rules and regulations.

In our view, the claim that the stronger business assistance results are necessarily spurious cannot be substantiated. ${ }^{30,31}$ Certainly in the initial period there was some uncertainty as administrators worked out procedures for implementing living wage laws. But that does not imply the laws were ineffective in this period, and city administrators suggested otherwise. Furthermore, for many cities the newer results extending the data through 2002 reach further beyond the years of initial implementation of living wage laws. At the same time, though, we acknowledge that

\footnotetext{
${ }^{30}$ Based on their claim about business assistance laws, throughout their paper Brenner, et al. (2002) report results reclassifying workers covered by business assistance laws as "uncovered." They then report as an "independent" finding that our results are reversed, with positive wage effects for the uncovered. But of course this is not new information. It just repeats our results with the workers covered by business assistance laws relabeled.

${ }^{31}$ It is also important to clear up a related point about coverage made by Brenner, et al. (2002). In particular, in our earlier paper (Neumark and Adams, forthcoming (a)) we tried to substantiate our results indicating that living wages increased wages of low-wage workers by attempting to distinguish potentially covered workers from those who could not be covered. In the case of contractor-only laws, the potentially covered included those in industries that might have contracts (based on the city's law), while in the case of business assistance laws this could include the entire private sector, and hence give a figure upwards of 90 percent of the workforce. Brenner, et al., focus on this analysis in arguing that our estimates are flawed, yielding coverage numbers that are "far beyond what any previous observer had suggested was even a most high-end estimate of the coverage range for living wage laws" (2002, p. 14). It is clear from reading our paper, though, that we recognize this point exactly, and presented this analysis not as a serious attempt to estimate coverage, but as a specification check. As the study they used as the basis for the criticism stated quite clearly, "[T] he broadest definitions of potential coverage were chosen, so as not to exclude those that are potentially affected. In addition, at best, those workers who could in principle be covered are identified; actual coverage rates are surely much lower than those reported. Nonetheless, this classification probably distinguishes between workers more and less likely to be covered" (Neumark, 2002, p. 62).
} 
there is considerable uncertainty over how many workers are directly affected by business assistance living wage laws, in part because the types of assistance that may make an employer subject to the law may originate in a variety of city departments. In addition, as discussed earlier, we have to remember that our estimates can reflect broader effects of living wage campaigns, which conceivably had greater impacts on low-wage labor markets in cities where business assistance provisions were ultimately included in the living wage ordinances that were passed. Given this uncertainty, we view the development of a better understanding of the working of business assistance living wage laws as a high priority for future research.

Aside from these issues related to workers directly affected by business assistance living wage laws and the confounding influences of the living wage campaigns generally, contractor and business assistance provisions of living wage laws may have qualitatively different effects. We conjecture that a few factors could lead to stronger effects of business assistance provisions. In particular, in the case of a contractor-only law, it is typically required that employers pay the mandated wage to workers for work done as part of the contract. For example, the Oakland City Manager's declaration of compliance with the city's living wage law mandates “a prescribed minimum level of compensation to their employees for the time their employees work on City of Oakland contracts." Assuming that contractors' employees do some work on city contracts, as well as other work, employers can mitigate the costs of a living wage in a couple of ways. First, they can reallocate their higher-skilled or higher-seniority (and therefore higher-wage) labor to the contract work and their lower-wage labor to the non-contract work, in order to comply. This may still entail some inefficiencies but could moderate any cost-increasing effects of living wages. In addition, other than the barrier imposed by the minimum wage, employers could even reduce wages on non-contract work. Of course the extent to which employers can take these steps depends on the share of their business tied up in city contracts; if contracts are a small component 
of sales or labor costs, it is conceivable that the effects of a living wage law could be largely dissipated.

In contrast, there may be fewer avenues for mitigating the costs (and therefore the effects) of living wage laws for employers covered under business assistance provisions. For example, an establishment created with the help of business assistance from a city would appear to have no choice but to pay all employees no less than the mandated living wage for all of their work. In addition, while contractors can reduce the share of their business with the city in response to a living wage (and similarly cities can shift business to higher-wage employers), business assistance recipients may have less leeway as they may have accepted long-term benefits such as bond financing or tax relief in return for locating in the jurisdiction. In some cases, at least, relocation costs seem likely to far outweigh costs from shifting business away from city contracts. ${ }^{32}$

While these possible differences between contractor-only and business assistance living wage laws remain conjectures, we believe that investigations along these lines, and of whether business assistance laws are associated with other changes affecting low-wage labor markets (even including greater or more effective coverage of contractors), are critical. Even if the number of workers affected by business assistance laws is higher, this cannot explain why we seem to find virtually no effects of contractor-only laws, in contrast to strong effects of business assistance laws. Rather, these differences suggest some significant qualitative differences in the direct or indirect impacts of the two types of laws or of the consequences of the campaigns accompanying them.

\section{A Deeper Look at Poverty and Low-Income Families}

A potential limitation of our evidence that living wages reduce poverty is that it focuses

\footnotetext{
${ }^{32}$ Another difference is that contractors may be able to pass through a large share if not all of their increased costs to cities, whereas this option does not exist for business assistance recipients who operate in the private sector. This can explain the stronger disemployment effects of business assistance living wage laws, but not the stronger wage effects.
} 
exclusively on whether living wages on average move families past a specific threshold. Yet it is possible that living wages generate either gains or losses for lower-income families yet do not result in movements across the poverty threshold. If so, then our estimates of the effects of living wages on the probability that a family is poor could mask either positive or negative effects of living wages on other lower-income families.

We therefore report results from two related analyses intended to provide a more in-depth analysis of the distributional effects of living wages. First, we use the same difference-indifferences framework to estimate the impact of living wages on the "depth" of poverty among poor families. Depth is measured as the percentage by which the family's total income falls short of the poverty threshold, and the regression is estimated for this measure conditional on a family being poor. As long as this regression is interpreted as a conditional expectation, rather than a population regression function, then the "selection" on poverty is not problematic. This regression is potentially informative because it could reveal, for example, that living wages move families closer to the poverty threshold-in addition to the earlier results indicating that living wages move some families over this threshold-thus strengthening the conclusions regarding the positive effects of living wages. Alternatively, given the job loss associated with living wages, it could be that some initially poor families are pushed further below the poverty line, offsetting the beneficial effects reported above. ${ }^{33}$ Table 6 reports regressions for the depth of poverty, conditional on being poor. The estimates reveal no statistical evidence of effects of living wage laws, suggesting that the gains from living wages lifting some families above the poverty line are not offset by income

\footnotetext{
${ }^{33}$ For example, in the June 16, 2002 Orlando Sentinel, Richard Toikka of the Employment Policies Institute is quoted as suggesting that "the people who are least skilled get frozen out of the job market," so that "[t]hese ordinances push people further into poverty." And an April 8, 2002 article in Time noted criticism of our results on poverty for "narrowly focusing on families pushed just above the official poverty standard at the expense of those who lost their job."
} 
declines among some families below the poverty line. ${ }^{34}$

The second analysis provides a fuller description of the effects of living wages on family incomes among lower-income families. We revert to looking at specific thresholds, but expand the number of thresholds that we examine-ranging from one-quarter of the poverty threshold to two times the threshold-using exactly the same framework used to study the effects of living wages on poverty. We already discussed why living wages may have impacts below the poverty threshold. They may also have effects above the threshold. For example, although living wages are commonly pegged to the poverty threshold based on one adult worker, there may be positive effects because they are sometimes set higher (e.g., San Jose, Hartford, and Madison), or because families affected by living wages have more than one worker. There may also be indirect effects of living wages on higher-wage workers in low-income but non-poor families.

The results of these analyses are reported in Table 7 . Beginning with the thresholds well below the poverty threshold, we generally find no significant evidence that living wage laws either decrease or increase the probability that families are below one-quarter or one-half of the poverty threshold, consistent with the absence of effects of living wages on the depth of poverty experienced by poor families. However, the evidence in columns (5) and (6) indicates that living wages-particularly the business assistance variety-reduce the probability that families' incomes are below three-quarters of the poverty threshold. Columns (7) and (8) repeat the results for the poverty threshold from Table 4, indicating a stronger effect at this threshold than at three-quarters of the poverty line. The estimated effects are statistically significant and larger still at 1.5 times the poverty threshold, and here, interestingly, the point estimate is larger for contractor-only living

\footnotetext{
${ }^{34}$ When we estimated OLS regressions or Tobits including those at or above the poverty line, with "depth" for them defined as zero, the evidence again pointed to gains from living wage laws, presumably associated with pushing families to or above the poverty line.
} 
wage laws, which is puzzling in light of the earlier results. ${ }^{35}$ Finally, at twice the poverty threshold the estimates are still in the direction of living wage laws reducing poverty, but they are not significant.

Thus, this richer analysis of the effects of living wage laws on low-income families does nothing to overturn the conclusion that business assistance living wages deliver net benefits for these families. At none of the thresholds ranging from one-quarter to two times the poverty threshold do we find any evidence that living wages tend to push families below the threshold. Moreover, in addition to the results indicating that living wages reduce the probability that families are poor, the more-detailed description provided by the new estimates reported here also indicates some gains for families somewhat below and somewhat above the poverty threshold. On the other hand, the results could reasonably be read as suggesting that living wages do not help the poorest families, which is not entirely surprising since such families are less likely to have workers, or may have the lowest-wage workers most likely to bear the disemployment effects of living wages.

\section{Are the Wage, Employment, and Poverty Effects Inconsistent?}

Our final analysis explores the question of whether the wage, employment, and poverty results we find can be reconciled. In particular, do our results for those in the bottom tenth of the wage or skill distribution indicating a negative employment elasticity that outweighs the positive wage elasticity imply that earnings of low-wage workers must fall and poverty must rise? ${ }^{36}$

There are two issues raised by this criticism. The less fundamental issue is whether our elasticity estimates necessarily imply that living wages must make low-wage workers worse off.

\footnotetext{
${ }^{35}$ In Neumark (2001), relatively strong positive wage effects of contractor-only living wage laws on a narrow group of workers-unionized municipal employees-are detected.

${ }^{36}$ For example, the Indianapolis Chamber of Commerce quotes Richard Toikka of the Employment Policies Institute as viewing our evidence of poverty-reducing effects of living wages as "puzzling in view of the large employment losses." (See http://www.indychamber.com/publicpolicy/wagesetting.html.)
} 
Two points bear on this question. First, the samples for which the wage and employment effects are estimated are not completely comparable. In Section III, the wage effects are estimated for those with a wage below the $10^{\text {th }}$ centile of the wage distribution, while the employment effects that might be viewed as corresponding are estimated for those below the $10^{\text {th }}$ centile of the imputed wage distribution. But since employment rates rise with the imputed wage, the worker at the $10^{\text {th }}$ centile of the wage distribution is higher skill than the worker at the $10^{\text {th }}$ centile of the imputed wage distribution. Thus, if lower-wage, lower-skill workers experience the largest wage impact from living wages (which need not be the case, of course, given the spotty coverage), then the corresponding wage increase for the worker at or near the $10^{\text {th }}$ centile of the imputed wage distribution should be larger than our estimates indicate. But such a calculation would also be problematic, as among this subset of workers those with the highest offer wages are more likely to be employed. The problem is that we cannot readily estimate wage and employment effects for precisely the same individuals, using cross-sectional data. In contrast, with longitudinal data we could identify a set of individuals employed prior to a living wage, and then estimate the wage and employment effects for this group.

The second point regarding the impact of living wages on low-wage workers is that we should not focus solely on the bottom $10^{\text {th }}$ of the wage or skill distribution. Returning briefly to Tables 2 and 4, recall that we pointed out that there was some evidence of positive wage effects, and perhaps a hint of positive employment effects, for workers between the $10^{\text {th }}$ and $50^{\text {th }}$ centiles. In the first four columns of Table 8 we group all of these workers together to try to obtain more precise estimates, and re-estimate the wage and employment effects. For both wages and employment the point estimates of the effects of living wages are positive, especially for business assistance living wages, although generally not significant. Positive wage effects could stem from a number of sources, including direct living wage effects, spillover effects, or relative demand 
shifts. But higher employment coupled with higher wages would only result from shifts in demand toward higher-skilled labor. Indeed one of the criticisms leveled at living wages is that they may induce substitution toward more-skilled workers. ${ }^{37}$ The evidence, however, is not sufficiently sharp to establish effects on wages or employment higher up in the distribution, or to distinguish between effects stemming from substitution or direct ("ripple") effects on wages.

Finally, columns (5)-(8) report regression results for weekly earnings for those in the bottom $10^{\text {th }}$ and the $10^{\text {th }}-50^{\text {th }}$ centile range of the imputed wage distribution, including those with no earnings. Paralleling the wage and employment results, these estimates suggest that living wages on net do not affect weekly earnings of those in the bottom tenth of the imputed wage distribution, given offsetting wage and employment effects. But the point estimates are consistent with business assistance living wages generating gains between the $10^{\text {th }}$ and $50^{\text {th }}$ centiles, although the estimates are not statistically significant.

Together, this evidence suggests that living wages do not necessarily benefit the most disadvantaged; in fact the evidence on disemployment effects indicates that some low-skill workers are hurt by living wage laws, and on net these individuals are not helped. At the same time, it suggests that some lower-wage workers and lower-skill individuals-just not the lowestwage and lowest-skill-may be helped.

This discussion leads into the more fundamental point raised by the argument that the poverty-reduction effects that we find are not tenable, given that our estimates are most consistent with living wages hurting the lowest-wage workers. We have to remember that the mapping from

\footnotetext{
${ }^{37}$ Both sides concur on this point. A March 14, 2002 press release from the Employment Policies Institute cites its research director as stating "Living wage increases are not an efficient way to help the poor. By requiring employers to pay a higher wage for positions once considered entry-level, they will inadvertently attract higher skilled employees to the job ..." And the same press release cites a December, 2000 study by Robert Pollin, an advocate of living wages, noting that "The other possible effect on employment policies would be through labor substitution-i.e., firms replacing their existing minimum wage employees with workers having better credentials, which could occur even in the absence of any net job losses..." Curiously, though, Brenner, et al., suggest that positive employment effects for higher-skill workers would be "anomalous" (2002, p. 18).
} 
low-wage workers to low-income families is quite imperfect. While poor families are of course quite likely to have low-wage and low-skill members, many non-poor families also have such members (Burkhauser, Couch, and Wittenburg, 1996). Thus, policies that help (or hurt) subsets of low-wage workers or low-skill individuals do not necessarily reduce (or increase) poverty.

Moreover, many poor families have workers that earn relatively low wages or have relatively low skills, but are not necessarily in the bottom tenth of the distribution. Thus, policies that end up helping workers who are in a higher part of the wage distribution can reduce poverty.

As partial evidence on this issue, we combine information from the March ORG and ADF files, reported in columns (1) and (2) of Table 9. We focus on the imputed wage distribution, in Panel A of Table 9, rather than the actual, since the results on employment and earnings in Table 8 are based on the former. However, we also report the same calculations for the actual wage distribution, in Panel B, and the qualitative conclusions are generally similar. The figures in Panel A of Table 9 show that poor families are indeed much more likely to have an individual in the bottom tenth of the imputed wage distribution than non-poor families (37 percent of poor families versus 20 percent of non-poor families). However, poor families are also more likely to have members in the $10^{\text {th }}-25^{\text {th }}$ centile range ( 35 percent versus 25 percent) and the $25^{\text {th }}-50^{\text {th }}$ centile range (66 percent versus 34 percent). This implies that policies that raise earnings of individuals in the latter categories could reduce poverty. Moreover, this point is reinforced by the fact that a high percentage of poor families (66 percent) have an individual in the $25^{\text {th }}-50^{\text {th }}$ centile range of the imputed wage distribution. However, this percentage drops considerably for the actual wage distribution.

Furthermore, whether living wages lift a family out of poverty depends on how close the family is to the poverty line in the first place. The remaining columns of Table 9 present evidence on this point, first dividing up poor families by how far they are below the poverty threshold, and 
then doing the same for non-poor families, based on how far they are above the threshold. What the figures in columns (3)-(10) reveal is that, not surprisingly, the lowest-skill and lowest-wage workers are most heavily concentrated in families furthest below the poverty threshold. For example, columns (3) and (6) show that only 29 percent of families within $\$ 2,000$ of the poverty threshold have individuals in the bottom tenth of the skill distribution, versus 70 percent of families more than $\$ 10,000$ below the threshold. Columns (7)-(10) also show that many families above, but near, the poverty threshold have workers with wages between the $10^{\text {th }}$ and $50^{\text {th }}$ centiles, which would help explain the boost to incomes that living wages provide to lower-income, nonpoor families (and also perhaps help explain the poverty results via reducing the likelihood that these families fall into poverty). What these figures imply is that wage or employment effects of living wages among individuals in the $10^{\text {th }}-50^{\text {th }}$ centile range of the imputed wage distribution may have as much or more to do with poverty than the effects of living wages on those individuals below the $10^{\text {th }}$ centile. In particular, wage or employment gains among the former may well reduce poverty, irrespective of the wage gains and employment losses among the least-skilled. Thus, the anti-poverty effects of living wages need not be at all inconsistent with the apparently negative impact of living wages on employment of the lowest-skill individuals, if the anti-poverty effects are generated in part by gains among those with higher skills (although we remind the reader that we generally did not find statistically significant evidence of such gains).

The one type of evidence that the preceding figures does not cover is whether the income gains or losses generated by living wages--whether among the lowest-skill individuals or notactually occur among poor families. This comes back, of course, to the imperfect mapping between low-wage workers and low-income families. The discussion above is predicated on the income gains experienced by workers in the $10^{\text {th }}-50^{\text {th }}$ centile range of the wage distribution occurring for workers in poor families. While the data are consistent with this, we have not 
demonstrated such a finding.

This same point helps in interpreting what has sometimes been described as a contradiction between the anti-poverty effects of living wages that we find and other evidence suggesting that minimum wages if anything increase poverty (e.g., Neumark and Wascher, 2002; Golan, Perloff, and Wu, 2001; Neumark, Schweitzer, and Wascher, 1998). ${ }^{38}$ However, there is no necessary contradiction between evidence that living wages reduce poverty and evidence that minimum wages may increase poverty. The gains and losses from living wages may be of quite different magnitudes, and fall at different points in the distribution of family income, than do the gains and losses from minimum wages; this depends in part on the types of workers who are affected by these alternative mandated wage floors. Obviously, though, an important area for future research is to parse out the wage and employment effects of minimum wages and living wages at different points in the distribution of family incomes.

\section{Discussion and Conclusions}

This paper explores a number of issues regarding the effects of living wages on low-wage workers and low-income families. First, because the data with which we can evaluate living wages are relatively recent, we update some of our earlier analyses using data for 1996-2002, whereas previously we only used data through 2000. We also explore some criticisms of our earlier estimates. This newer analysis confirms our earlier findings that living wage laws boost wages of the lowest-wage workers, yet at the cost of disemployment effects. It also confirms our earlier findings that living wage laws reduce poverty in the urban areas in which they have been enacted. These statements generally hold more strongly for the broader living wage laws that extend coverage to employers getting business assistance from cities, than for narrower living

\footnotetext{
${ }^{38}$ For example, discussing the poverty results, an April 8, 2002 article in Time attributed to living wage advocates the view of one of the authors of this paper as "a conservative minimum-wage basher converted by the success of living wages."
} 
wages laws that for the most part cover only city contractors. While qualitatively similar, in the updated estimates the wage and poverty effects are a bit more moderate than in our earlier findings.

Second, we provide an analysis of the effects of living wages that goes beyond just asking whether living wages reduce poverty. We do not find that living wages increase the depth of poverty among families that remain poor-pushing their incomes further below the poverty linebelying the criticism that the anti-poverty effects we have found are offset by making some poor families worse off. In fact, we find that families somewhat below and somewhat above the poverty line are also helped by living wages.

Finally, we explore the distributional effects of living wages, and the potential differences between their effects on low-wage workers and their effects on low-income families. We focus in particular on the question of how living wages can reduce poverty if, as the evidence suggests, they impose employment losses on the lowest-skill individuals that seem to offset the wage gains that low-wage workers experience. We note that poverty reductions need not stem from income gains for the lowest-wage or lowest-skill individuals, and present evidence suggesting that they may stem from gains for other workers who are nonetheless in poor families.

This last point emphasizes that distributional effects of policies that affect workers differentially-with effects on workers varying depending on wages and skills, as well as varying across workers with similar wages and skills-can be quite complicated and not effectively summarized by "average" effects. The new evidence we present suggests that living wage effects should be viewed as somewhat of a mixed bag. They reduce poverty, but they do not appear to accomplish this by helping the lowest-wage, lowest-skill individuals. ${ }^{39}$ In fact, they may reduce poverty by generating income gains for other workers, despite generating some negative effects

\footnotetext{
${ }^{39}$ A related question of interest is how living wages affect different demographic groups: young versus old, minorities versus non-minorities, single-parent versus two-parent families, etc.
} 
for those at the very bottom of the wage or skill distribution. These latter negative effects do not necessarily undermine the case for living wages. It may simply be an uncomfortable fact that trying to help low-income families through mandating higher wage floors tends to have negative consequences for the least-skilled workers, since such wage floors may amount to a "tax" on the employment of such workers. Rather, what these results imply is that even if wage floors deliver some benefits to low-income families-as appears to be the case for living wages-additional policies are needed to help the most disadvantaged, whether in the form of a safety net to help those left without jobs, or strategies to enhance skills and make them more employable and at higher wages.

Finally, one puzzle we have emphasized is the considerably stronger effects we find when living wage ordinances include provisions covering recipients of business assistance from cities. We believe this is a robust result, and we believe that we have identified strong evidence of changes in labor markets associated with these types of living wage laws. At the same time, the evidence is most consistent with important qualitative differences between contractor-only laws and those that include business assistance provisions. Greater coverage of business assistance laws may be part of the explanation, but it seems unlikely to be the whole explanation. Whether the remaining difference arises because of different direct impacts of the laws, different indirect impacts in changing norms or voluntary adoption of higher wages to attract assistance, differences in other aspects of living wage laws that include business assistance provisions, or broader effects stemming from living wage campaigns, remain as open-and critical-questions for future research. 


\section{References}

Bertrand, Marianne, Esther Duflo, and Sendhil Mullainathan. (2001). How much should we trust differences-in-differences estimates? Unpublished paper, University of Chicago.

Brenner, Mark D. (2003). The economic impact of the Boston living wage ordinance. Unpublished paper, Political Economy Research Institute, University of Massachusetts-Amherst.

Brenner, Mark D., Jeannette Wicks-Lim, and Robert Pollin. (2002). Measuring the impact of living wage laws: a critical appraisal of David Neumark's "How Living Wage Laws Affect Low-Wage Workers and Low-Income Families." (Working Paper No. 43) Amherst, MA: Political Economy Research Institute.

Burkhauser, Richard V., Kenneth A. Couch, and David C. Wittenburg. (1996). 'Who gets what' from minimum wage hikes: a re-estimation of Card and Krueger's distributional analysis in Myth and Measurement: The New Economics of the Minimum Wage. Industrial and Labor Relations Review 49 (3), 547-52.

Fairris, David. (2003). The impact of living wages on employers: a control group analysis of the Los Angeles ordinance. Unpublished paper, University of California-Riverside.

Golan, Amos, Jeffrey M. Perloff, and Ximing Wu. (2001). Welfare effects of minimum wage and other government policies. Unpublished paper, University of California-Berkeley.

Koenker, Roger, and Kevin F. Hallock. (2001). Quantile regression. Journal of Economic Perspectives 15 (4), 143-56.

Mood, Alexander, Franklin A. Graybill, and Duane C. Boes. (1974). Introduction to the theory of statistics. New York: McGraw-Hill Book Company.

Neumark, David. (2002). How living wage laws affect low-wage workers and low-income families. San Francisco: Public Policy Institute of California.

Neumark, David. (2001). Living wages: protection for or protection from low-wage workers? (Working Paper No. 8393). Cambridge, MA: National Bureau of Economic Research.

Neumark, David, and Scott Adams. Detecting effects of living wage laws. Forthcoming (a) in Industrial Relations.

Neumark, David, and Scott Adams. Do living wage ordinances reduce urban poverty? Forthcoming (b) in Journal of Human Resources.

Neumark, David, Mark Schweitzer, and William Wascher. Minimum wage effects throughout the wage distribution. Forthcoming in Journal of Human Resources.

Neumark, David, Mark Schweitzer, and William Wascher. (1998). The effects of minimum wages on the distribution of family incomes: a non-parametric analysis. (Working Paper No. 6536). Cambridge, MA: National Bureau of Economic Research. 
Neumark, David, and William Wascher. (2002). Do minimum wages fight poverty? Economic Inquiry 40 (3), 315-33.

Pollin, Robert, and Stephanie Luce. (1998). The living wage: building a fair economy. New York: The New Press.

Sander, Richard, and Sean Lokey. (1998). The Los Angeles living wage: the first eighteen months. Unpublished paper, UCLA and the Fair Housing Institute, Los Angeles.

U.S. Bureau of the Census. (1997). CPS technical paper 63: design \& methodology. Washington, DC. 
Table 1: Information on Living Wage Laws

\begin{tabular}{|c|c|c|c|}
\hline City & $\begin{array}{l}\text { Initial month that law was } \\
\text { effective }\end{array}$ & $\begin{array}{l}\text { Living wage requirement as } \\
\text { of December } 2002\end{array}$ & Coverage \\
\hline (1) & (2) & (3) & (4) \\
\hline Ann Arbor & April 2001 & 8.70 & $\mathrm{~B}, \mathrm{C}$ \\
\hline Baltimore & July 1995 & 8.20 & $\mathrm{C}$ \\
\hline Bellingham & December 2002 & 10.00 & $\mathrm{C}$ \\
\hline Boston & October 1998 & 10.25 & $\mathrm{C}$ \\
\hline Burlington & December 2001 & 9.90 & $\mathrm{C}, \mathrm{M}$ \\
\hline Charlottesville & December 2001 & 8.00 & $\mathrm{C}$ \\
\hline Chicago & August 1998 & 9.05 & $\mathrm{C}$ \\
\hline Cleveland & January 2001 & 9.20 & $\mathrm{~B}, \mathrm{C}, \mathrm{M}$ \\
\hline Dayton & April 1998 & 7.00 & M \\
\hline Denver & March 2000 & 8.70 & $\mathrm{C}$ \\
\hline Detroit & December 1998 & 9.05 & $\mathrm{~B}, \mathrm{C}$ \\
\hline Duluth & August 1997 & 6.50 & B \\
\hline Durham & February 2002 & 8.45 & $\mathrm{C}, \mathrm{M}$ \\
\hline Gainesville & October 2001 & 8.56 & M \\
\hline Hartford & October 1999 & 9.96 & $\mathrm{~B}, \mathrm{C}$ \\
\hline Jersey City & July 1996 & 7.50 & $\mathrm{C}$ \\
\hline Los Angeles & April 1997 & 8.17 & $\mathrm{~B}, \mathrm{C}$ \\
\hline Madison & April 1999 & 9.05 & $\mathrm{~B}, \mathrm{M}$ \\
\hline Milwaukee & December 1995 & 7.22 & $\mathrm{C}$ \\
\hline Minneapolis & April 1997 & 9.05 & B \\
\hline New Haven & May 1997 & 10.86 & $\mathrm{C}$ \\
\hline Oakland & April 1998 & 8.72 & $\mathrm{~B}, \mathrm{C}$ \\
\hline Portland & July 1996 & 8.00 & $\mathrm{C}$ \\
\hline Rochester & January 2001 & 8.76 & $\mathrm{~B}, \mathrm{C}, \mathrm{M}$ \\
\hline San Antonio & August 1998 & 9.27 & B \\
\hline San Francisco & September 2000 & 10.00 & $\mathrm{C}$ \\
\hline San Jose & December 1998 & 10.36 & $\mathrm{~B}, \mathrm{C}, \mathrm{M}$ \\
\hline Toledo & June 2000 & 9.96 & $\mathrm{~B}, \mathrm{C}$ \\
\hline Tucson & October 1999 & 8.57 & $\mathrm{~B}, \mathrm{C}$ \\
\hline
\end{tabular}

Note: We list the cities large enough to be identified in our CPS data, along with the first complete month in which the law was effective. Because most cities adjust their wage requirements based upon federal poverty guidelines, inflation rates, or some other means, we list the wage requirement as of December 2002, the last month included in our sample. Some cities impose a higher living wage if health insurance is not provided; the table reports the lower wage floor. We also classify the coverage of laws into several categories, including B (firms receiving some form of business assistance from the city, broadly defined), $\mathrm{C}$ (city contractors and/or subcontractors), and $\mathrm{M}$ (municipal employees). We exclude cities that passed a law but do not currently enforce the law for one of a number of reasons (Buffalo, Omaha, Pittsburgh, and St. Louis). Most of the information in this table is updated information from Neumark and Adams (forthcoming ( $a$ and $b)$ ), which contain more detail about each city's law. 
Table 2: Estimated Effects of Living Wages on the Log Wages of Workers, 1996-2002

\begin{tabular}{|c|c|c|c|c|c|c|c|c|}
\hline & \multicolumn{2}{|c|}{$<10^{\text {th }}$ centile } & \multicolumn{2}{|c|}{$10^{\text {th }}-25^{\text {th }}$ centile } & \multicolumn{2}{|c|}{$25^{\text {th }}-50^{\text {th }}$ centile } & \multicolumn{2}{|c|}{$50^{\text {th }}-75^{\text {th }}$ centile } \\
\hline & (1) & (2) & (3) & (4) & (5) & (6) & (7) & (8) \\
\hline Living wage & $\begin{array}{c}-0.72 \\
(2.25)\end{array}$ & $\ldots$ & $\begin{array}{c}2.20 \\
(1.44)\end{array}$ & $\ldots$ & $\begin{array}{c}2.64 \\
(1.92)\end{array}$ & $\ldots$ & $\begin{array}{c}1.07 \\
(1.59)\end{array}$ & $\ldots$ \\
\hline$\times$ business assistance coverage & $\ldots$ & $\begin{array}{c}0.73 \\
(2.56)\end{array}$ & $\ldots$ & $\begin{array}{c}3.37 \\
(2.13)\end{array}$ & $\ldots$ & $\begin{array}{c}1.89 \\
(2.12)\end{array}$ & $\ldots$ & $\begin{array}{c}0.66 \\
(1.99)\end{array}$ \\
\hline$\times$ contractors only & $\ldots$ & $\begin{array}{l}-3.19 \\
(4.08)\end{array}$ & $\cdots$ & $\begin{array}{c}0.23 \\
(1.31)\end{array}$ & $\ldots$ & $\begin{array}{c}3.70 \\
(2.67)\end{array}$ & $\ldots$ & $\begin{array}{c}1.62 \\
(2.37)\end{array}$ \\
\hline Living wage 6 months ago & $\begin{array}{c}-1.35 \\
(2.74)\end{array}$ & $\ldots$ & $\begin{array}{c}1.57 \\
(1.27) \\
\end{array}$ & $\ldots$ & $\begin{array}{c}3.33 \\
(1.83) \\
\end{array}$ & $\ldots$ & $\begin{array}{c}1.48 \\
(1.57) \\
\end{array}$ & $\ldots$ \\
\hline$\times$ business assistance coverage & $\ldots$ & $\begin{array}{c}0.91 \\
(3.46)\end{array}$ & $\ldots$ & $\begin{array}{c}2.48 \\
(1.32)\end{array}$ & $\ldots$ & $\begin{array}{c}3.74 \\
(1.52)\end{array}$ & $\ldots$ & $\begin{array}{c}2.26 \\
(1.93)\end{array}$ \\
\hline$\times$ contractors only & $\ldots$ & $\begin{array}{l}-5.41 \\
(3.20)\end{array}$ & $\ldots$ & $\begin{array}{c}-0.23 \\
(1.76)\end{array}$ & $\ldots$ & $\begin{array}{c}2.26 \\
(3.15)\end{array}$ & $\ldots$ & $\begin{array}{c}-0.24 \\
(2.20)\end{array}$ \\
\hline Living wage 12 months ago & $\begin{array}{c}4.01 \\
(2.97)\end{array}$ & $\ldots$ & $\begin{array}{c}1.42 \\
(2.01)\end{array}$ & $\ldots$ & $\begin{array}{c}1.18 \\
(2.37)\end{array}$ & $\ldots$ & $\begin{array}{c}0.25 \\
(1.78)\end{array}$ & $\ldots$ \\
\hline$\times$ business assistance coverage & $\ldots$ & $\begin{array}{c}6.35 \\
(3.79)\end{array}$ & $\ldots$ & $\begin{array}{c}1.98 \\
(1.88)\end{array}$ & $\ldots$ & $\begin{array}{c}1.07 \\
(2.33)\end{array}$ & $\ldots$ & $\begin{array}{c}-0.12 \\
(1.58)\end{array}$ \\
\hline$\times$ contractors only & $\ldots$ & $\begin{array}{l}-0.27 \\
(3.68)\end{array}$ & $\ldots$ & $\begin{array}{c}0.01 \\
(3.06)\end{array}$ & $\ldots$ & $\begin{array}{c}0.70 \\
(3.15)\end{array}$ & $\ldots$ & $\begin{array}{c}0.67 \\
(2.62)\end{array}$ \\
\hline Sample size & \multicolumn{2}{|c|}{46,374} & \multicolumn{2}{|c|}{58,101} & \multicolumn{2}{|c|}{96,040} & \multicolumn{2}{|c|}{98,267} \\
\hline Mean wage & \multicolumn{2}{|c|}{5.60} & \multicolumn{2}{|c|}{7.90} & \multicolumn{2}{|c|}{11.10} & \multicolumn{2}{|c|}{16.64} \\
\hline
\end{tabular}

Reported are the estimated effects of the living wage on the wage of individuals in the range of an SMSA's wage distribution specified at the top of each column. Contemporaneous, six-month, and 12-month lag coefficients are estimated from separate specifications. Standard errors are reported in parentheses. All estimates are multiplied by 100. For an SMSA's data to be included in the sample for a particular month, there must be at least 25 observations in that SMSA-month cell. Observations for which allocated information is required to construct the wage variable in the CPS are dropped. The log wage equation controls for year, month, SMSA, education, age, marital status, race, gender, and the minimum wage at the same lag as the living wage variable. Odd-numbered columns include separate linear trends for cities passing no living wage laws and cities passing living wage laws, and even-numbered columns separate the trends for cities passing contractor-only living wage laws and cities passing business assistance living wage laws. Reported standard errors are robust to non-independence (and heteroscedasticity) within city cells, following the suggestions in Bertrand, Duflo, and Mullainathan (2001). 
Table 3: Examination of Critiques in Brenner, et al. (2002)

\begin{tabular}{|c|c|c|c|c|}
\hline 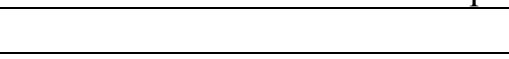 & \multicolumn{4}{|c|}{ A. Alternative Methods of Estimating Effects of Living Wages on Log Wages, 1996-2000 } \\
\hline & \multicolumn{2}{|c|}{ Previous analyses } & \multirow{2}{*}{$\begin{array}{l}\text { Quantile regression at } \\
10^{\text {th }} \text { centile, } \\
\text { conditioning on skill } \\
\text { (Brenner, et al.) }\end{array}$} & \multirow{2}{*}{$\begin{array}{l}\text { Quantile regression } \\
\text { at } 10^{\text {th }} \text { centile, } \\
\text { without conditioning } \\
\text { on skill }\end{array}$} \\
\hline & $\begin{array}{l}<10^{\text {th }} \text { centile, } \\
\text { individual data }\end{array}$ & $\begin{array}{l}10^{\text {th }} \text { centile, city-month } \\
\text { data }\end{array}$ & & \\
\hline & $(1)$ & $(2)$ & (3) & (4) \\
\hline \multirow[t]{3}{*}{ Living wage 12 months ago } & $\begin{array}{l}6.95 \\
(2.40) \\
\end{array}$ & $\begin{array}{c}4.61 \\
(1.99)\end{array}$ & $\begin{array}{c}0.74 \\
(1.57)\end{array}$ & $\begin{array}{c}7.00 \\
(1.83)\end{array}$ \\
\hline & \multicolumn{4}{|c|}{ B. Estimates Including and Excluding Los Angeles } \\
\hline & \multicolumn{2}{|c|}{$\begin{array}{l}<10^{\text {th }} \text { centile, individual data, } \\
\text { full sample }\end{array}$} & \multicolumn{2}{|c|}{$\begin{array}{l}<10^{\text {th }} \text { centile, individual data, } \\
\text { excluding Los Angeles }\end{array}$} \\
\hline \multicolumn{5}{|l|}{ Living wage } \\
\hline$\times$ business assistance coverage & \multicolumn{2}{|c|}{$\begin{array}{c}1.78 \\
(2.76) \\
\end{array}$} & \multicolumn{2}{|c|}{$\begin{array}{c}1.73 \\
(3.06) \\
\end{array}$} \\
\hline$\times$ contractors only & \multicolumn{2}{|c|}{$\begin{array}{l}-4.50 \\
(3.45)\end{array}$} & \multicolumn{2}{|c|}{$\begin{array}{l}-4.37 \\
(3.44)\end{array}$} \\
\hline \multicolumn{5}{|l|}{ Living wage 6 months ago } \\
\hline$\times$ business assistance coverage & \multicolumn{2}{|c|}{$\begin{array}{c}5.83 \\
(2.66)\end{array}$} & \multicolumn{2}{|c|}{$\begin{array}{c}5.75 \\
(3.02)\end{array}$} \\
\hline$\times$ contractors only & \multicolumn{2}{|c|}{$\begin{array}{l}-5.23 \\
(3.66)\end{array}$} & \multicolumn{2}{|c|}{$\begin{array}{l}-5.21 \\
(3.65)\end{array}$} \\
\hline \multicolumn{5}{|l|}{ Living wage 12 months ago } \\
\hline$\times$ business assistance coverage & \multicolumn{2}{|c|}{$\begin{array}{l}10.54 \\
(2.78)\end{array}$} & \multicolumn{2}{|c|}{$\begin{array}{l}11.71 \\
(3.29)\end{array}$} \\
\hline$\times$ contractors only & \multicolumn{2}{|c|}{$\begin{array}{c}0.50 \\
(4.02)\end{array}$} & \multicolumn{2}{|c|}{$\begin{array}{c}0.53 \\
(4.02) \\
\end{array}$} \\
\hline
\end{tabular}

Estimations explained in text. In column (2) of Panel A, the data are weighted by the number of observations in the city-month cell; when the dependent variable is a centile for a cell rather than a mean, this is the correct weighting scheme as long as the density is the same across cells (Mood, Graybill, and Boes, 1974). The standard errors in columns (3) and (4) of Panel A are bootstrapped. In this table only, because the results pertain to findings in our earlier papers and estimates paralleling those in our earlier papers, the data, specifications, and methods correspond to those in Neumark and Adams (forthcoming (a) and (b)). 
Table 4: Estimated Effects of Living Wages on the Probability of Employment of Individuals, 1996-2002

\begin{tabular}{|c|c|c|c|c|c|c|c|c|}
\hline & \multicolumn{2}{|c|}{$<10^{\text {th }}$ centile } & \multicolumn{2}{|c|}{$10^{\text {th }}-25^{\text {th }}$ centile } & \multicolumn{2}{|c|}{$25^{\text {th }}-50^{\text {th }}$ centile } & \multicolumn{2}{|c|}{$50^{\text {th }}-75^{\text {th }}$ centile } \\
\hline & (1) & (2) & (3) & (4) & (5) & (6) & (7) & (8) \\
\hline Living wage & $\begin{array}{l}-1.04 \\
(3.40)\end{array}$ & $\ldots$ & $\begin{array}{c}0.25 \\
(2.35)\end{array}$ & $\ldots$ & $\begin{array}{c}1.36 \\
(1.33)\end{array}$ & $\cdots$ & $\begin{array}{l}-0.07 \\
(1.37)\end{array}$ & $\ldots$ \\
\hline$\times$ business assistance coverage & $\ldots$ & $\begin{array}{c}-1.29 \\
(4.08) \\
\end{array}$ & $\ldots$ & $\begin{array}{c}0.39 \\
(2.75) \\
\end{array}$ & $\ldots$ & $\begin{array}{c}1.31 \\
(1.54) \\
\end{array}$ & $\ldots$ & $\begin{array}{c}1.15 \\
(1.83) \\
\end{array}$ \\
\hline$\times$ contractors only & $\ldots$ & $\begin{array}{c}-1.05 \\
(4.26)\end{array}$ & $\ldots$ & $\begin{array}{c}-0.13 \\
(3.71)\end{array}$ & $\ldots$ & $\begin{array}{c}1.20 \\
(1.78)\end{array}$ & $\ldots$ & $\begin{array}{l}-2.25 \\
(2.06)\end{array}$ \\
\hline Living wage 6 months ago & $\begin{array}{l}-2.40 \\
(2.24)\end{array}$ & $\ldots$ & $\begin{array}{c}0.80 \\
(2.18)\end{array}$ & $\ldots$ & $\begin{array}{c}0.64 \\
(1.44)\end{array}$ & $\cdots$ & $\begin{array}{c}-1.20 \\
(1.42)\end{array}$ & $\cdots$ \\
\hline$\times$ business assistance coverage & $\ldots$ & $\begin{array}{l}-2.10 \\
(2.91)\end{array}$ & $\ldots$ & $\begin{array}{c}1.24 \\
(2.43)\end{array}$ & $\ldots$ & $\begin{array}{c}0.42 \\
(1.15)\end{array}$ & $\ldots$ & $\begin{array}{c}-0.42 \\
(1.94)\end{array}$ \\
\hline$\times$ contractors only & $\ldots$ & $\begin{array}{l}-3.66 \\
(2.55)\end{array}$ & $\ldots$ & $\begin{array}{l}-0.23 \\
(3.72)\end{array}$ & $\ldots$ & $\begin{array}{c}0.50 \\
(3.29)\end{array}$ & $\ldots$ & $\begin{array}{l}-2.71 \\
(1.72)\end{array}$ \\
\hline Living wage 12 months ago & $\begin{array}{c}-5.25 \\
(2.35)\end{array}$ & $\ldots$ & $\begin{array}{c}0.49 \\
(2.33)\end{array}$ & $\ldots$ & $\begin{array}{c}0.59 \\
(1.45)\end{array}$ & $\cdots$ & $\begin{array}{c}-0.77 \\
(1.60)\end{array}$ & $\cdots$ \\
\hline$\times$ business assistance coverage & $\ldots$ & $\begin{array}{c}-7.39 \\
(1.79)\end{array}$ & $\ldots$ & $\begin{array}{c}0.57 \\
(2.25)\end{array}$ & $\ldots$ & $\begin{array}{c}0.47 \\
(1.54)\end{array}$ & $\ldots$ & $\begin{array}{l}-2.60 \\
(2.08)\end{array}$ \\
\hline$\times$ contractors only & $\ldots$ & $\begin{array}{c}-2.88 \\
(3.45)\end{array}$ & $\ldots$ & $\begin{array}{c}-0.07 \\
(4.55)\end{array}$ & $\ldots$ & $\begin{array}{c}0.18 \\
(3.24)\end{array}$ & $\ldots$ & $\begin{array}{c}1.82 \\
(1.82)\end{array}$ \\
\hline Sample size & \multicolumn{2}{|c|}{116,466} & \multicolumn{2}{|c|}{165,799} & \multicolumn{2}{|c|}{276,182} & \multicolumn{2}{|c|}{279,272} \\
\hline Mean employment rate & \multicolumn{2}{|c|}{43.37} & \multicolumn{2}{|c|}{58.80} & \multicolumn{2}{|c|}{68.86} & \multicolumn{2}{|c|}{78.77} \\
\hline
\end{tabular}

Reported are the estimated effects of the living wage on the employment of individuals in the range of an SMSA's imputed wage distribution specified at the top of each column. Estimates are from linear probability models. Contemporaneous, six-month, and 12-month lag coefficients are estimated from separate specifications. Standard errors are reported in parentheses. All estimates are multiplied by 100. For an SMSA's data to be included in the sample for a particular month, there must be at least 25 observations in that SMSA-month cell. Observations for which allocated information is required to construct the employment variable in the CPS are dropped. The employment equation controls for year, month, SMSA, education, age, marital status, race, gender, and the minimum wage at the same lag as the living wage variable. Oddnumbered columns include separate linear trends for cities passing no living wage laws and cities passing living wage laws, and even-numbered columns separate the trends for cities passing contractor-only living wage laws and cities passing business assistance living wage laws.

Reported standard errors are robust to non-independence (and heteroscedasticity) within city cells. 
Table 5: Estimated Effects of Living Wages on the Probability that Family Income Falls Below the Poverty Threshold, 1995-2001

\begin{tabular}{|c|c|c|}
\hline & (1) & $(2)$ \\
\hline Living wage as of December & $\begin{array}{c}0.54 \\
(2.01)\end{array}$ & ... \\
\hline $\mathrm{x}$ business assistance coverage & ... & $\begin{array}{c}1.28 \\
(2.74)\end{array}$ \\
\hline $\mathrm{x}$ coverage for contractors only & $\ldots$ & $\begin{array}{c}0.33 \\
(2.25)\end{array}$ \\
\hline Living wage as of June & $\begin{array}{c}-0.92 \\
(2.24)\end{array}$ & $\ldots$ \\
\hline $\mathrm{x}$ business assistance coverage & $\ldots$ & $\begin{array}{c}-0.95 \\
(3.04) \\
\end{array}$ \\
\hline $\mathrm{x}$ coverage for contractors only & $\ldots$ & $\begin{array}{c}0.14 \\
(1.81)\end{array}$ \\
\hline Living wage as of January & $\begin{array}{c}-3.42 \\
(1.27)\end{array}$ & $\ldots$ \\
\hline $\mathrm{x}$ business assistance coverage & $\ldots$ & $\begin{array}{c}-3.23 \\
(1.53)\end{array}$ \\
\hline $\mathrm{x}$ coverage for contractors only & $\ldots$ & $\begin{array}{c}-2.14 \\
(1.99)\end{array}$ \\
\hline Sample size & \multicolumn{2}{|c|}{142,421} \\
\hline Mean poverty rate & \multicolumn{2}{|c|}{18.61} \\
\hline
\end{tabular}

Reported are the estimated effects of the living wage on whether a family's income is below the poverty threshold, using linear probability models. All estimates are multiplied by 100 . Given that the ADF surveys are conducted in March and information on family earnings and income refer to the prior calendar year, the applicable contemporaneous and lagged minimum and living wages are noted in the left-hand column. Coefficients for living wages as of December, June, and January are estimated from separate specifications. The equation includes dummy variables for year and SMSA. Column (1) includes separate linear trends for cities passing no living wage laws and cities passing living wage laws, and column (2) separates the trends for cities passing contractor-only living wage laws and cities passing business assistance living wage laws. Observations for which allocated information is required to construct the income variable in the CPS are dropped. Reported standard errors are robust to non-independence (and heteroscedasticity) within city cells. 
Table 6: Estimated Effects of Living Wages on the Depth of Poverty, Conditional on Being Poor, 1995-2001

\begin{tabular}{|c|c|c|}
\hline & (1) & (2) \\
\hline Living wage as of December & $\begin{array}{c}2.51 \\
(3.45)\end{array}$ & $\cdots$ \\
\hline$\times$ business assistance coverage & $\ldots$ & $\begin{array}{c}1.34 \\
(4.35) \\
\end{array}$ \\
\hline$\times$ coverage for contractors only & $\cdots$ & $\begin{array}{c}5.09 \\
(4.75) \\
\end{array}$ \\
\hline Living wage as of June & $\begin{array}{c}2.49 \\
(3.62)\end{array}$ & ... \\
\hline$\times$ business assistance coverage & $\ldots$ & $\begin{array}{c}1.35 \\
(4.06)\end{array}$ \\
\hline$\times$ coverage for contractors only & ... & $\begin{array}{c}6.38 \\
(5.82)\end{array}$ \\
\hline Living wage as of January & $\begin{array}{c}0.92 \\
(3.98)\end{array}$ & $\cdots$ \\
\hline$\times$ business assistance coverage & $\ldots$ & $\begin{array}{l}-1.29 \\
(4.22) \\
\end{array}$ \\
\hline$\times$ coverage for contractors only & $\cdots$ & $\begin{array}{c}6.35 \\
(6.73)\end{array}$ \\
\hline Sample size & \multicolumn{2}{|c|}{27,404} \\
\hline Mean poverty depth & \multicolumn{2}{|c|}{57.44} \\
\hline
\end{tabular}

Reported are the estimated effects of the living wage on the percentage by which a family's income falls below the poverty threshold, for the subsample of poor families. See notes to Table 5 for other details. 
Table 7: Estimated Effects of Living Wages on the Probability that Family Income Falls Below a Given Multiple of the Poverty Threshold, 1995-2001

\begin{tabular}{|c|c|c|c|c|c|c|c|c|c|c|c|c|}
\hline & \multicolumn{2}{|c|}{$\begin{array}{l}1 / 4 \text { of poverty } \\
\text { threshold }\end{array}$} & \multicolumn{2}{|c|}{$\begin{array}{c}1 / 2 \text { of poverty } \\
\text { threshold }\end{array}$} & \multicolumn{2}{|c|}{$\begin{array}{c}3 / 4 \text { of poverty } \\
\text { threshold }\end{array}$} & \multicolumn{2}{|c|}{$\begin{array}{l}\text { Poverty } \\
\text { threshold }\end{array}$} & \multicolumn{2}{|c|}{$\begin{array}{c}1.5 \text { times poverty } \\
\text { threshold }\end{array}$} & \multicolumn{2}{|c|}{$\begin{array}{c}2 \text { times poverty } \\
\text { threshold }\end{array}$} \\
\hline & (1) & (2) & (3) & (4) & (5) & $(6)$ & (7) & $(8)$ & (9) & $(10)$ & (11) & $(12)$ \\
\hline $\begin{array}{l}\text { Living wage as of } \\
\text { December }\end{array}$ & $\begin{array}{c}0.11 \\
(1.29) \\
\end{array}$ & $\cdots$ & $\begin{array}{c}0.96 \\
(1.81) \\
\end{array}$ & $\cdots$ & $\begin{array}{c}1.13 \\
(2.00) \\
\end{array}$ & $\cdots$ & $\begin{array}{c}0.54 \\
(2.01) \\
\end{array}$ & $\cdots$ & $\begin{array}{l}-0.85 \\
(2.12)\end{array}$ & $\cdots$ & $\begin{array}{c}0.81 \\
(1.95)\end{array}$ & $\cdots$ \\
\hline $\begin{array}{l}\times \text { business assistance } \\
\text { coverage }\end{array}$ & $\ldots$ & $\begin{array}{c}0.01 \\
(1.71) \\
\end{array}$ & $\ldots$ & $\begin{array}{c}1.52 \\
(2.37) \\
\end{array}$ & $\ldots$ & $\begin{array}{c}1.94 \\
(2.57) \\
\end{array}$ & $\ldots$ & $\begin{array}{c}1.28 \\
(2.74) \\
\end{array}$ & $\ldots$ & $\begin{array}{c}0.35 \\
(2.68) \\
\end{array}$ & $\cdots$ & $\begin{array}{l}-0.05 \\
(2.35) \\
\end{array}$ \\
\hline$\times$ contractors only & $\ldots$ & $\begin{array}{c}0.62 \\
(1.36) \\
\end{array}$ & $\ldots$ & $\begin{array}{c}0.63 \\
(2.02) \\
\end{array}$ & $\ldots$ & $\begin{array}{c}0.64 \\
(2.36) \\
\end{array}$ & $\ldots$ & $\begin{array}{c}0.33 \\
(2.25) \\
\end{array}$ & $\ldots$ & $\begin{array}{l}-1.72 \\
(2.63) \\
\end{array}$ & $\ldots$ & $\begin{array}{r}2.47 \\
(3.20) \\
\end{array}$ \\
\hline Living wage as of June & $\begin{array}{l}-0.18 \\
(1.47) \\
\end{array}$ & $\ldots$ & $\begin{array}{c}0.01 \\
(2.08) \\
\end{array}$ & $\ldots$ & $\begin{array}{c}0.39 \\
(2.02) \\
\end{array}$ & $\ldots$ & $\begin{array}{c}-0.92 \\
(2.24) \\
\end{array}$ & $\cdots$ & $\begin{array}{l}-2.79 \\
(2.32) \\
\end{array}$ & $\ldots$ & $\begin{array}{l}-2.30 \\
(2.04) \\
\end{array}$ & $\cdots$ \\
\hline $\begin{array}{l}\times \text { business assistance } \\
\text { coverage }\end{array}$ & $\ldots$ & $\begin{array}{l}-0.58 \\
(1.90) \\
\end{array}$ & $\ldots$ & $\begin{array}{l}-0.14 \\
(2.70) \\
\end{array}$ & $\ldots$ & $\begin{array}{c}0.28 \\
(2.67) \\
\end{array}$ & $\ldots$ & $\begin{array}{l}-0.95 \\
(3.04) \\
\end{array}$ & $\ldots$ & $\begin{array}{l}-2.03 \\
(3.02) \\
\end{array}$ & $\cdots$ & $\begin{array}{l}-2.37 \\
(2.87) \\
\end{array}$ \\
\hline$\times$ contractors only & $\ldots$ & $\begin{array}{c}1.24 \\
(1.56)\end{array}$ & $\ldots$ & $\begin{array}{c}0.92 \\
(1.88)\end{array}$ & $\ldots$ & $\begin{array}{c}1.41 \\
(1.71)\end{array}$ & $\ldots$ & $\begin{array}{c}0.14 \\
(1.81)\end{array}$ & $\ldots$ & $\begin{array}{l}-3.18 \\
(1.82)\end{array}$ & $\ldots$ & $\begin{array}{l}-1.66 \\
(2.29)\end{array}$ \\
\hline $\begin{array}{l}\text { Living wage as of } \\
\text { January }\end{array}$ & $\begin{array}{l}-1.14 \\
(1.11) \\
\end{array}$ & $\ldots$ & $\begin{array}{l}-1.28 \\
(1.16) \\
\end{array}$ & $\ldots$ & $\begin{array}{l}-2.09 \\
(1.06) \\
\end{array}$ & $\ldots$ & $\begin{array}{l}-3.42 \\
(1.27) \\
\end{array}$ & $\ldots$ & $\begin{array}{l}-4.66 \\
(1.80) \\
\end{array}$ & $\cdots$ & $\begin{array}{l}-3.31 \\
(2.24) \\
\end{array}$ & $\cdots$ \\
\hline $\begin{array}{l}\times \text { business assistance } \\
\text { coverage }\end{array}$ & $\ldots$ & $\begin{array}{l}-1.73 \\
(1.14)\end{array}$ & $\cdots$ & $\begin{array}{l}-1.53 \\
(1.12)\end{array}$ & $\ldots$ & $\begin{array}{l}-2.13 \\
(0.88)\end{array}$ & $\ldots$ & $\begin{array}{l}-3.23 \\
(1.53)\end{array}$ & $\ldots$ & $\begin{array}{l}-3.82 \\
(2.42)\end{array}$ & $\ldots$ & $\begin{array}{l}-3.16 \\
(3.22)\end{array}$ \\
\hline$\times$ contractors only & $\ldots$ & $\begin{array}{c}0.58 \\
(1.77) \\
\end{array}$ & $\ldots$ & $\begin{array}{c}0.03 \\
(1.87) \\
\end{array}$ & $\ldots$ & $\begin{array}{l}-0.75 \\
(1.92) \\
\end{array}$ & $\ldots$ & $\begin{array}{l}-2.14 \\
(1.99) \\
\end{array}$ & $\ldots$ & $\begin{array}{l}-4.51 \\
(2.26) \\
\end{array}$ & $\ldots$ & $\begin{array}{l}-2.81 \\
(2.94) \\
\end{array}$ \\
\hline
\end{tabular}

Reported are the estimated effects of the living wage on whether a family's income is below the multiple of the poverty threshold given in the column heading, using linear probability models. See notes to Table 5 for other details. 
Table 8: Estimated Effects of Living Wages on Log Wages, Employment, and Weekly Earnings, 1996-2002

\begin{tabular}{|c|c|c|c|c|c|c|c|c|}
\hline & \multirow{2}{*}{\multicolumn{2}{|c|}{$\begin{array}{c}\text { Log wages } \\
10^{\text {th }}-50^{\text {th }} \text { centile of } \\
\text { distribution }\end{array}$}} & \multirow{2}{*}{\multicolumn{2}{|c|}{$\begin{array}{c}\text { Employment } \\
10^{\text {th }}-50^{\text {th }} \text { centile of } \\
\text { imputed distribution }\end{array}$}} & \multicolumn{4}{|c|}{ Weekly earnings } \\
\hline & & & & & \multicolumn{2}{|c|}{$\begin{array}{c}\text { Below } 10^{\text {th }} \text { centile of } \\
\text { imputed wage } \\
\text { distribution }\end{array}$} & \multicolumn{2}{|c|}{$\begin{array}{l}10^{\text {th }}-50^{\text {th }} \text { centile of } \\
\text { imputed distribution }\end{array}$} \\
\hline & $(1)$ & (2) & (3) & (4) & $(5)$ & $(6)$ & $(7)$ & $(8)$ \\
\hline Living wage & $\begin{array}{c}2.01 \\
(1.42) \\
\end{array}$ & $\ldots$ & $\begin{array}{c}1.26 \\
(1.22) \\
\end{array}$ & $\ldots$ & $\begin{array}{c}4.51 \\
(6.13) \\
\end{array}$ & $\ldots$ & $\begin{array}{c}17.91 \\
(10.03) \\
\end{array}$ & $\ldots$ \\
\hline$\times$ business assistance coverage & $\ldots$ & $\begin{array}{c}1.76 \\
(1.84)\end{array}$ & $\ldots$ & $\begin{array}{c}1.26 \\
(1.41)\end{array}$ & $\ldots$ & $\begin{array}{c}9.30 \\
(7.20)\end{array}$ & $\ldots$ & $\begin{array}{c}22.59 \\
(14.94)\end{array}$ \\
\hline$\times$ contractors only & $\ldots$ & $\begin{array}{c}2.31 \\
(1.66)\end{array}$ & $\ldots$ & $\begin{array}{c}1.06 \\
(1.54)\end{array}$ & $\ldots$ & $\begin{array}{c}-3.83 \\
(10.58)\end{array}$ & $\ldots$ & $\begin{array}{c}9.99 \\
(7.67)\end{array}$ \\
\hline Living wage 6 months ago & $\begin{array}{c}2.70 \\
(1.45) \\
\end{array}$ & $\ldots$ & $\begin{array}{c}1.11 \\
(1.46) \\
\end{array}$ & $\ldots$ & $\begin{array}{c}4.22 \\
(5.08) \\
\end{array}$ & $\ldots$ & $\begin{array}{c}12.59 \\
(10.94) \\
\end{array}$ & $\ldots$ \\
\hline$\times$ business assistance coverage & $\ldots$ & $\begin{array}{c}3.06 \\
(1.44)\end{array}$ & $\ldots$ & $\begin{array}{c}1.04 \\
(1.31)\end{array}$ & $\ldots$ & $\begin{array}{c}7.79 \\
(6.55)\end{array}$ & $\ldots$ & $\begin{array}{c}22.48 \\
(15.73)\end{array}$ \\
\hline$\times$ contractors only & $\ldots$ & $\begin{array}{c}1.84 \\
(2.28)\end{array}$ & $\ldots$ & $\begin{array}{c}0.84 \\
(3.07)\end{array}$ & $\ldots$ & $\begin{array}{l}-2.06 \\
(7.09)\end{array}$ & $\ldots$ & $\begin{array}{c}-3.72 \\
(10.37)\end{array}$ \\
\hline Living wage 12 months ago & $\begin{array}{c}1.70 \\
(2.04) \\
\end{array}$ & $\ldots$ & $\begin{array}{c}1.06 \\
(1.42) \\
\end{array}$ & $\ldots$ & $\begin{array}{c}4.08 \\
(7.73) \\
\end{array}$ & $\ldots$ & $\begin{array}{c}8.13 \\
(9.79) \\
\end{array}$ & $\ldots$ \\
\hline$\times$ business assistance coverage & $\ldots$ & $\begin{array}{c}2.07 \\
(1.93) \\
\end{array}$ & $\ldots$ & $\begin{array}{c}1.16 \\
(1.24)\end{array}$ & $\ldots$ & $\begin{array}{c}3.61 \\
(8.12)\end{array}$ & $\ldots$ & $\begin{array}{c}18.85 \\
(12.88)\end{array}$ \\
\hline$\times$ contractors only & $\ldots$ & $\begin{array}{c}0.69 \\
(2.97)\end{array}$ & ... & $\begin{array}{c}0.40 \\
(3.27)\end{array}$ & $\ldots$ & $\begin{array}{c}4.36 \\
(13.92)\end{array}$ & $\ldots$ & $\begin{array}{c}-8.74 \\
(13.59)\end{array}$ \\
\hline Sample size & \multicolumn{2}{|c|}{154,141} & \multicolumn{2}{|c|}{441,981} & \multicolumn{2}{|c|}{116,466} & \multicolumn{2}{|c|}{441,981} \\
\hline Mean & \multicolumn{2}{|c|}{9.88} & \multicolumn{2}{|c|}{65.00} & \multicolumn{2}{|c|}{85.77} & \multicolumn{2}{|c|}{244.45} \\
\hline
\end{tabular}

See notes to Tables 2 and 4 for description of specifications in columns (1)-(4). Reported in columns (5)-(8) are OLS estimates of the effects of the living wage on weekly earnings of individuals in the range of an SMSA's imputed wage distribution specified at the top of each column. In columns (1)-(4), observations for which allocated information is required to construct the log wage or employment variables in the CPS are dropped. In columns (5)-(8) observations with allocated wages are retained, to avoid understatement of the proportion of individuals employed because allocated wages can only occur for those who are employed. Like the wage and employment equations, the weekly earnings equation controls for year, month, SMSA, education, age, marital status, race, gender, and the minimum wage at the same lag as the living wage variable, and includes the same trends for different cities described in the notes to Tables 2 and 4 . Reported standard errors are robust to non-

independence (and heteroscedasticity) within city cells. The weekly earnings variable is constructed by multiplying the usual hours worked by the hourly wage for hourly workers. For non-hourly workers, reported weekly earnings are used. For non-workers, weekly earnings are set to zero. 
Table 9: Wages of Family Members, Family Poverty Status, and Distance Below Poverty Threshold, 1996-2002

\begin{tabular}{|c|c|c|c|c|c|c|c|c|c|c|}
\hline \multicolumn{11}{|c|}{ A. Based on Imputed Wages } \\
\hline & & & \multicolumn{4}{|c|}{$\begin{array}{c}\text { In poverty } \\
\text { (thousands of dollars below threshold) }\end{array}$} & \multicolumn{4}{|c|}{$\begin{array}{l}\text { Not in poverty } \\
\text { (thousands of dollars above threshold) }\end{array}$} \\
\hline & $\begin{array}{c}\text { In } \\
\text { poverty }\end{array}$ & $\begin{array}{l}\text { Not in } \\
\text { poverty }\end{array}$ & $>10$ & $4-10$ & $2-4$ & $<2$ & $<2$ & $2-4$ & $4-10$ & $>10$ \\
\hline & $(1)$ & $(2)$ & (3) & $(4)$ & $(5)$ & (6) & (7) & $(8)$ & $(9)$ & $(10)$ \\
\hline $\begin{array}{l}\text { At least one family } \\
\text { member: } \\
<10^{\text {th }} \text { centile }\end{array}$ & 37.05 & 19.87 & 69.61 & 36.15 & 31.37 & 29.28 & 24.32 & 24.01 & 21.10 & 19.35 \\
\hline $10^{\text {th }}-25^{\text {th }}$ centile & 35.10 & 24.79 & 64.43 & 35.29 & 29.40 & 27.45 & 26.77 & 26.46 & 22.56 & 24.87 \\
\hline $25^{\text {th }}-50^{\text {th }}$ centile & 66.05 & 34.36 & 74.65 & 65.79 & 68.23 & 61.70 & 57.83 & 53.65 & 49.90 & 30.89 \\
\hline $50^{\text {th }}-75^{\text {th }}$ centile & 40.51 & 53.85 & 42.66 & 38.70 & 41.36 & 43.19 & 46.05 & 46.73 & 51.71 & 54.63 \\
\hline$>75^{\text {th }}$ centile & 14.90 & 54.75 & 15.63 & 14.40 & 13.57 & 16.98 & 16.29 & 18.70 & 22.42 & 61.34 \\
\hline \multicolumn{11}{|c|}{ B. Based on Actual Wages } \\
\hline $\begin{array}{l}\text { At least one family } \\
\text { member: } \\
<10^{\text {th }} \text { centile }\end{array}$ & 37.29 & 12.36 & 44.04 & 40.30 & 31.72 & 33.34 & 32.27 & 25.40 & 18.37 & 10.46 \\
\hline $10^{\text {th }}-25^{\text {th }}$ centile & 33.60 & 17.46 & 30.96 & 31.77 & 36.45 & 35.68 & 31.88 & 35.84 & 31.14 & 14.62 \\
\hline $25^{\text {th }}-50^{\text {th }}$ centile & 24.84 & 31.38 & 20.80 & 23.07 & 28.93 & 26.64 & 27.82 & 34.79 & 40.91 & 30.19 \\
\hline $50^{\text {th }}-75^{\text {th }}$ centile & 6.20 & 34.85 & 6.05 & 5.83 & 5.92 & 7.27 & 8.71 & 9.30 & 14.81 & 39.14 \\
\hline$>75^{\text {th }}$ centile & 3.03 & 31.37 & 4.02 & 2.78 & 3.21 & 2.73 & 3.22 & 2.68 & 4.32 & 36.71 \\
\hline
\end{tabular}

Imputed wages and wages are taken from March ORGs. Poverty status is taken from the March ADFs, for sample members in the March ORGs. Because the ORGs cover the current month, and the ADFs the previous calendar year, wages and family income/poverty are not perfectly aligned. 
Figure 1: Quantile Analysis and Conditioning on Skill

A. Analysis without conditioning on skill: Does $10^{\text {th }}$ centile shift with living wage?

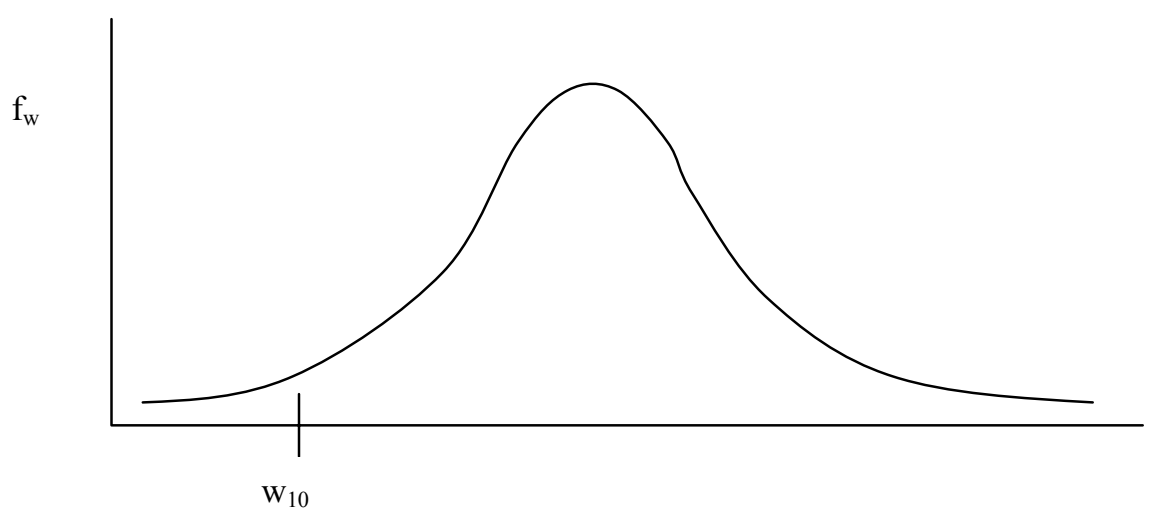

B. Conditional-on-skill analysis: Does $10^{\text {th }}$ centile regression line shift with living wage?

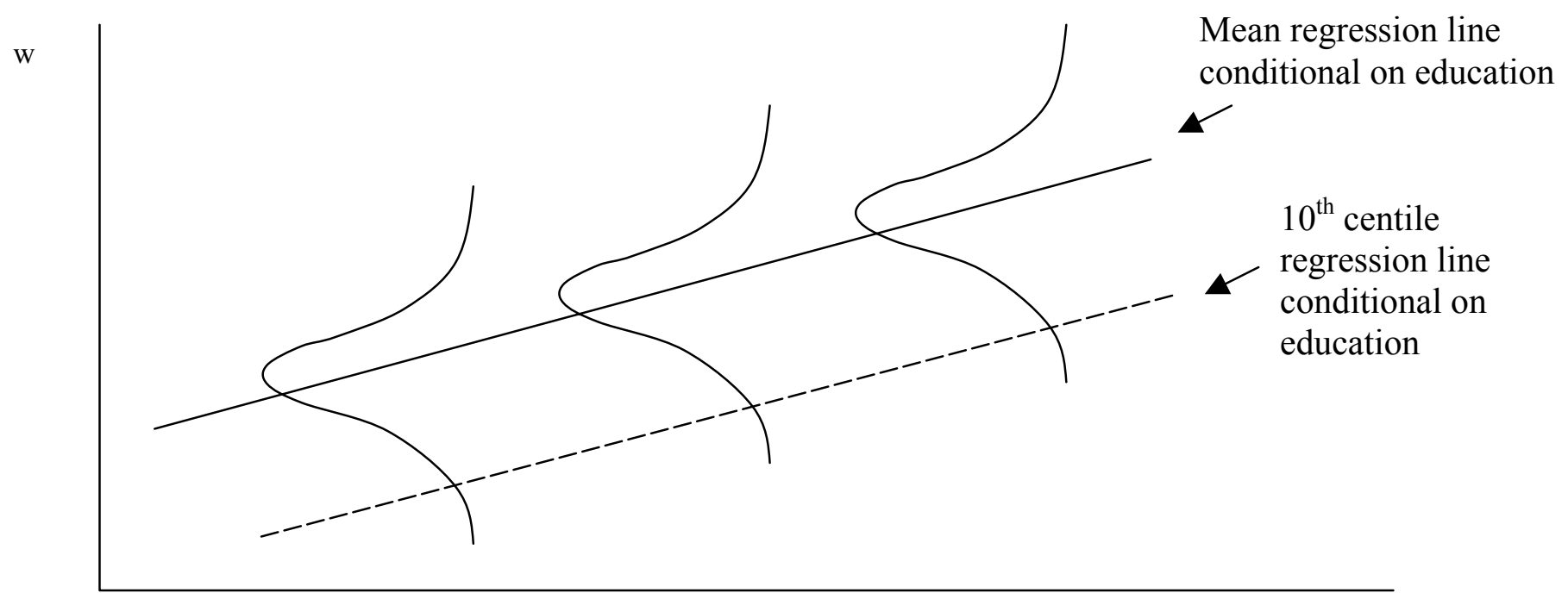

Education 